\title{
MicroRNAs in Neuroinflammation: Implications in Disease Pathogenesis, Biomarker Discovery and Therapeutic Applications
}

\author{
Jessy A. Slota ${ }^{1,2}$ and Stephanie A. Booth ${ }^{1,2, *}$ \\ 1 Prion Diseases Section, Public Health Agency of Canada, National Microbiology Laboratory, \\ 1015 Arlington St., Winnipeg, MB R3E 3R2, Canada; slotaj@myumanitoba.ca \\ 2 Department of Medical Microbiology and Infectious Diseases, Faculty of Health Sciences, University of \\ Manitoba, 730 William Ave., Winnipeg, MB R3E 0W3, Canada \\ * Correspondence: stephanie.booth@canada.ca; Tel.: +1-204-789-6031
}

Received: 28 March 2019; Accepted: 22 April 2019; Published: 24 April 2019

\begin{abstract}
The central nervous system can respond to threat via the induction of an inflammatory response. Under normal circumstances this response is tightly controlled, however uncontrolled neuroinflammation is a hallmark of many neurological disorders. MicroRNAs are small non-coding RNA molecules that are important for regulating many cellular processes. The ability of microRNAs to modulate inflammatory signaling is an area of ongoing research, which has gained much attention in recent years. MicroRNAs may either promote or restrict inflammatory signaling, and either exacerbate or ameliorate the pathological consequences of excessive neuroinflammation. The aim of this review is to summarize the mode of regulation for several important and well-studied microRNAs in the context of neuroinflammation, including miR-155, miR-146a, miR-124, miR-21 and let-7. Furthermore, the pathological consequences of miRNA deregulation during disorders that feature neuroinflammation are discussed, including Multiple Sclerosis, Alzheimer's disease, Parkinson's disease, Prion diseases, Japanese encephalitis, Herpes encephalitis, ischemic stroke and traumatic brain injury. There has also been considerable interest in the use of altered microRNA signatures as biomarkers for these disorders. The ability to modulate microRNA expression may even serve as the basis for future therapeutic strategies to help treat pathological neuroinflammation.
\end{abstract}

Keywords: microRNA; neuroinflammation; neurodegeneration; central nervous system; immunity; biomarkers; therapeutics

\section{Brain Immunity and Neuroinflammation}

The central nervous system (CNS) is traditionally thought of as an immune-privileged site, separated from peripheral immune cells that are unable to cross the blood brain barrier (BBB) under normal conditions [1]. In response to threat, resident glial cells including microglia and astrocytes become activated and induce an inflammatory response through pro-inflammatory cytokines, chemokines, secondary messengers and reactive oxygen species (ROS) [2]. This response, termed neuroinflammation, may be beneficial, by protecting the brain from pathogens and neurotoxic agents and promoting tissue repair processes [3,4]. Conversely, uncontrolled neuroinflammation can cause pathogenic tissue damage within the CNS through elevated glial cell activation, BBB permeability and infiltration of peripheral immune cells [5]. These changes ultimately lead to increased levels of pro-inflammatory mediators within the CNS, many of which are neurotoxic and can induce neurodegeneration [5]. Although neuroinflammation is a component of many neurological disorders, it is often difficult to elucidate the role played by these processes as there are both beneficial and harmful aspects of neuroinflammation [4]. Indeed, a balance must be struck between protecting the brain from 
threats, while preventing damage from uncontrolled inflammation. Therefore, understanding the cellular and molecular players that control neuroinflammation is an area of ongoing interest which may shed light on the pathogenic mechanisms behind neurological disease and lead to the discovery of novel therapeutics.

Among the principal CNS resident cells that mediate neuroinflammation are microglia, a specialized long-term resident macrophage that develops early during embryogenesis from myeloid precursor cells [6]. Under normal conditions within the CNS, microglia are traditionally thought to exist in a "quiescent" or "resting" state in which they continuously scan the surrounding microenvironment and help maintain brain homeostasis through roles in synapse organization, removal of debris by phagocytosis and release of neurotrophic factors [7]. Microglia express an array of pattern recognition receptors, cytokine receptors and neuronal receptors which can respond to a variety of pathogen associated molecular patterns (PAMPs), danger associated molecular patterns (DAMPs) and other molecular signatures, triggering signaling that leads to microglial activation [8]. Activation of microglia is accompanied by morphological changes; quiescent microglia are characterized by a ramified morphology, but upon activation they take on an amoeboid form which permits motility and phagocytosis [7]. Depending on the nature of the signals that lead to their activation, microglia may differentiate into either M1 (pro-inflammatory) or M2 (anti-inflammatory) phenotypes which resemble those seen in macrophages. M2 microglia release anti-inflammatory and protective cytokines such as IL-10, TGF- $\beta$, IL-4 and IL-13, which promotes wound healing and tissue repair [9]. M1 microglia release inflammatory mediators such as ROS, MMP-9 and pro-inflammatory cytokines such as TNF $\alpha$, IL-6 and IL-1 $\beta$ [10]. The balance between these different microglial phenotypic states may promote inflammation or tissue repair and influence the progression of neuroinflammatory disorders [10].

Astrocytes are another functionally diverse glial cell type within the brain parenchyma that may influence the inflammatory response of the CNS to various stimuli [11]. In the normal healthy brain, astrocytes help to maintain homeostasis through metabolic support, regulation of synaptogenesis, removal of excessive neurotransmitters in the extracellular space, and through interactions with the neuronal signaling system [12]. Astrocytes also play important roles in the CNS response to stress and disease. Reactive astrogliosis, a heterogeneous spectrum of molecular and cellular changes within astrocytes following activation, is a hallmark pathology of many disorders of the CNS [13]. Neuroinflammation may be either promoted or restricted by astrocytes through a variety of mechanisms, including release of pro-inflammatory and anti-inflammatory molecules, regulation of leukocyte recruitment into the CNS and by serving as functional barriers for the CNS parenchyma [14].

Beyond the contributions made by individual cell types, neuroinflammation is regulated through complex signaling cascades between different cell types within the CNS. For instance, the neurovascular unity (NVU) is a structure formed from neurons, astrocytes, extracellular matrix and the brain microvascular endothelium which plays a pivotal role in controlling the neuroinflammatory response [15]. At the center of the NVU are astrocytes, which contact both the vascular endothelium via their astrocytic end-feet and neurons through synapses, allowing intercommunication between blood vessels and neurons within the CNS [16]. This network allows for regulation of blood flow, brain development, BBB permeability, clearance of toxic by-products and immune surveillance [17]. The NVU enables communication between the CNS and peripheral immune system through regulation of BBB permeability and leukocyte entry, which can promote neuroinflammation during a variety of brain pathologies [18].

Accordingly, it is clear that neuroinflammation is mediated through the complex interplay between cells within the CNS and the periphery. Although the brain inflammatory response is tightly controlled in the healthy brain by numerous regulatory mechanisms, under pathological states these processes may become deregulated leading to uncontrolled neuroinflammation [4]. Among the central regulators of these processes are microRNAs (miRNAs), which may either become deregulated, contributing to disease progression, or may reflect a homeostatic attempt of the CNS to prevent excessive damage and restore normal conditions. 


\section{MicroRNAs}

MicroRNAs are a group of short, non-coding RNA molecules of approximately 22 nucleotides in length which post-transcriptionally regulate the expression of mRNA through the RNA interference pathway [19]. The genes encoding miRNAs are transcribed by RNA polymerase II, resulting in the primary miRNA transcript (pri-miRNA), which is usually over $1 \mathrm{kbp}$ and forms a stem-loop structure [20]. However, in some cases transcription of miRNA may be carried out by RNA polymerase III [21]. The microprocessor complex is formed by the RNAse III type endonuclease Drosha and DCGR8, which cleaves the pri-miRNA within the nucleus into a small, $\sim 65 \mathrm{nt}$ RNA hairpin known as a pre-miRNA [22]. The pre-miRNA is then exported into the cytoplasm where it is cleaved near the terminal loop by Dicer, another RNAse III endonuclease [23]. This liberates a small RNA duplex containing the mature miRNA sequences which is subsequently loaded into the RNA-induced silencing complex (RISC).

The mature RISC is formed by argonaute (AGO) proteins which bind the miRNA duplex and remove the passenger miRNA strand [24]. The guide strand is selected based on the thermodynamic stability of the two ends of the RNA duplex. The strand that has a less thermodynamically stable $5^{\prime}$ terminus is usually selected as the guide, although this is not always the case and may be cell type specific [25]. The target mRNA molecules are recognized by sequence complementarity to the miRNA seed sequence, corresponding to positions 2-8 of the $5^{\prime}$-end of the guide strand [26]. Perfect complementarity between the miRNA and the target sequence usually results in cleavage of the target between nucleotides 10 and 11 by the PIWI domain of Ago [27]. Mammalian miRNAs usually bind their targets via incomplete complementarity, which leads to translational repression either through interference with the translational machinery or by targeting the mRNA for deadenylation and decay [28].

The expression of more than half of all protein coding genes is likely controlled by the over 2500 miRNAs that have been annotated in the human genome [29,30]. Each miRNA may regulate many, even hundreds of different mRNA molecules and multiple miRNAs may regulate the same mRNA [31]. MiRNAs are themselves subject to regulation at several levels including the transcriptional level and at each of the steps of their biogenesis [20]. They can also be released from cells in small membrane bound extracellular vesicles (ECV's) that can be internalized by other cells, thereby enabling miRNAs to participate in intercellular communication [32]. Thus miRNAs represent an important regulatory system with diverse functions and unsurprisingly, miRNAs have been found to play roles in a variety of different diseases [33].

\section{Key miRNAs Which Regulate Neuroinflammation}

Neuroinflammation is among the many processes which are regulated by miRNA. A few miRNAs have been well studied in the context of neuroinflammation. Inflammatory processes may be promoted by miRNAs, such as miR-155, or suppressed by miRNAs including miR-146a, miR-124 and miR-21. Some miRNAs, such as the let-7 family may either promote or inhibit the induction of the inflammatory response.

\section{1. $m i R-155$}

MiR-155 is a central proinflammatory mediator of the CNS which is induced within macrophages and microglia in response to NF- $\mathrm{KB}$ dependent TLR signaling [34-37]. Targets of miR-155 include anti-inflammatory regulators such as SOCS1 [34,36], SHIP1 [38], C/EBP- $\beta$ [39] and IL13R $\alpha 1$ [40]. Therefore, miR-155 lifts repression of inflammatory signaling by these suppressive factors, and accordingly contributes to the induction of neuroinflammation. Within microglia, miR-155 is able to promote inflammation by a second pathway. When miR-155 expression is induced by the transcription factor p53 it subsequently targets the transcription factor c-Maf, which induces differentiation and anti-inflammatory responses in immune cells [41]. Furthermore, p53 also suppresses c-Maf through 
the induction of two additional microRNAs, miR-34a and miR-145, which target Twist2, an activator of c-Maf expression [41]. By suppressing the anti-inflammatory transcription factor c-Maf, miR-155 along with miR-34a and miR-145 promote inflammatory responses.

\section{2. $\operatorname{miR}-146 a$}

MiR-146a is a negative regulator of inflammation which is expressed in neurons, microglia and astrocytes and is also induced by TLR signaling through NF-KB [42-44]. MiR-146a acts as a negative feedback regulator of NF-KB signaling by targeting components of the MyD88 signaling complex, including IRAK1 and TRAF6 [42,44,45]. MiR-146a targets other proinflammatory mediators including STAT-1 [46,47], IRF-5 [47] and CFH [44,48]. Macrophage polarization is also modulated by miR-146a through the Notch1 pathway, with miR-146a expression promoting M2 polarization [49]. Therefore miR-146a serves to diminish inflammatory signaling within the CNS following stimulation by NF- $\mathrm{KB}$, helping to limit excessive neuroinflammation.

\section{3. $m i R-124$}

MiR-124 is an anti-inflammatory miRNA that is considered to be brain specific as it is involved in the regulation of neuronal differentiation [50] and under normal conditions is highly expressed in microglia, but not peripheral macrophages [51]. However, the expression of miR-124 may be induced in monocytes and macrophages in response to the Th2 cytokines IL-4 and IL-10 [52]. The induction of miR-124 in macrophages leads to anti-inflammatory effects such as downregulation of TLR-6 and MyD88 [53], and polarization towards an M2 phenotype [52]. Similarly, miR-124 promotes a quiescent state in microglia by targeting the transcription factor C/EBP- $\alpha$ and its downstream target PU.1, which are master regulators of polarization in macrophages and monocytes [51]. Expression of miR-124 in microglia has also been shown to reduce inflammation through downregulation of TNF- $\alpha$ and MHC-II, as well as a reduction in ROS [54]. Indeed, miR-124 appears to regulate the polarization of microglia along with other key miRNA regulators of neuroinflammation. Downregulation of miR-124, miR-689 and miR-711 in microglia coincides with a transition away from resting state (M0), and other miRNA control the outcome of this activation; with increased miR-155 expression associated with pro-inflammatory (M1) polarization whereas increased miR-145 expression is associated with anti-inflammatory (M2) polarization [55]. Clearly, miR-124 is a key negative regulator of neuroinflammation by reducing inflammatory mediators and restricting microglia to an inactive state.

\section{4. $m i R-21$}

Although miR-21 is highly expressed in a variety of active immune cells such as macrophages, mast-cells, neutrophils and T-cells [56], it plays important roles in various cell types of the CNS including microglia [57], astrocytes [58], neurons [59] and oligodendrocytes [60]. MiR-21 is another anti-inflammatory regulator that is induced by TLR signaling through MyD88 and NF- $\mathrm{KB}$, and targets PDCD4, leading to downregulation of NF- $\mathrm{KB}$ and induction of the anti-inflammatory cytokine IL-10 [61]. Furthermore, miR-21 mediates anti-inflammatory effects in macrophages by decreasing TNF- $\alpha$ secretion [62,63], although it also inhibits M2 polarization by targeting STAT-3 [64]. MiR-21 is also induced in astrocytes in response to stress, and serves to impair astrocytic activation during the early stages of astrogliosis [65]. 


\subsection{Let-7}

Let-7 is a family of evolutionary conserved miRNA, of which there are nine in humans that generally serve as tumor suppressors and regulators of developmental processes yet remain highly expressed in adult tissues [66]. The let-7 miRNAs also serve as important modulators of neuroinflammatory processes. Let-7 miRNAs are known to promote polarization of macrophages into the anti-inflammatory M2 phenotype by targeting the C/EBP- $\delta$ transcription factor [67] as well as inhibit apoptosis and promote the M2 phenotype in microglia [68]. Let-7 is further able to modulate inflammation by targeting the cytokines IL-6 and IL-10 [69] in addition to the receptor TLR4 [70]. Along with miR-125, let-7 promotes differentiation of astrocytes by targeting negative regulators of this process within glial progenitor cells [71]. Interestingly, let-7 may also promote activation of microglia and macrophages by serving as a DAMP for TLR7 [72,73]. The let-7 family are important regulators of various inflammatory processes within the CNS where they may serve either pro-inflammatory, or anti-inflammatory, roles.

\subsection{MiRNAs In Neuroinflammatory Signaling}

The cumulative effect of the miR-155, miR-146a, miR-124, miR-21 and let-7 on inflammatory signaling pathways is summarized in Figure 1. The action of multiple miRNAs on these pathways may be either synergistic or antagonistic. For instance, both miR-146a and miR-21 target different components of the TLR/MyD88/NF-kB and JAK-STAT pathways, jointly working to suppress activation of these pathways $[44,46,61,64]$. Conversely miR-155 promotes activation of the JAK-STAT pathway by targeting the repressors SOCS1 and SHIP1 [36,38]. TLRs are an important component of the neuroinflammatory response and are targeted by miR-124 and let-7, although let-7 may also lead to TLR activation by serving as a DAMP [53,70,72]. The C/EBP family of transcription factors are important for various inflammatory processes such as M1/M2 polarization, and are targeted by miR-124, miR-155 and let-7 [39,51,67].

It is interesting to note that miR-155, miR-146a, miR-124 and miR-21 are all induced in response to MyD88/NF- $\mathrm{kB}$ dependent signaling [37,42,53,61], implying that they work together to "fine-tune" the neuroinflammatory response. However, the effect of individual miRNAs is cell-type and context dependent as miRNAs may only target transcripts which are actively being expressed. It is likely that these miRNAs have roles in the CNS outside of regulating inflammatory signaling, such as regulating neuronal processes. The presence of miRNAs in extracellular vesicles such as exosomes allows them to participate in intercellular communication [32]. MiR-124, miR-21 and let-7 have been found in exosomes released from neurons, regulating nearby cells such as microglia [74-76]. This raises the possibility that even miRNAs expressed in neurons may contribute to inflammatory signaling should they act on neighboring glial cells. Therefore, regulation by miRNA is highly complex, subject to fluctuation and should be carefully assessed in the context of neuroinflammation. 


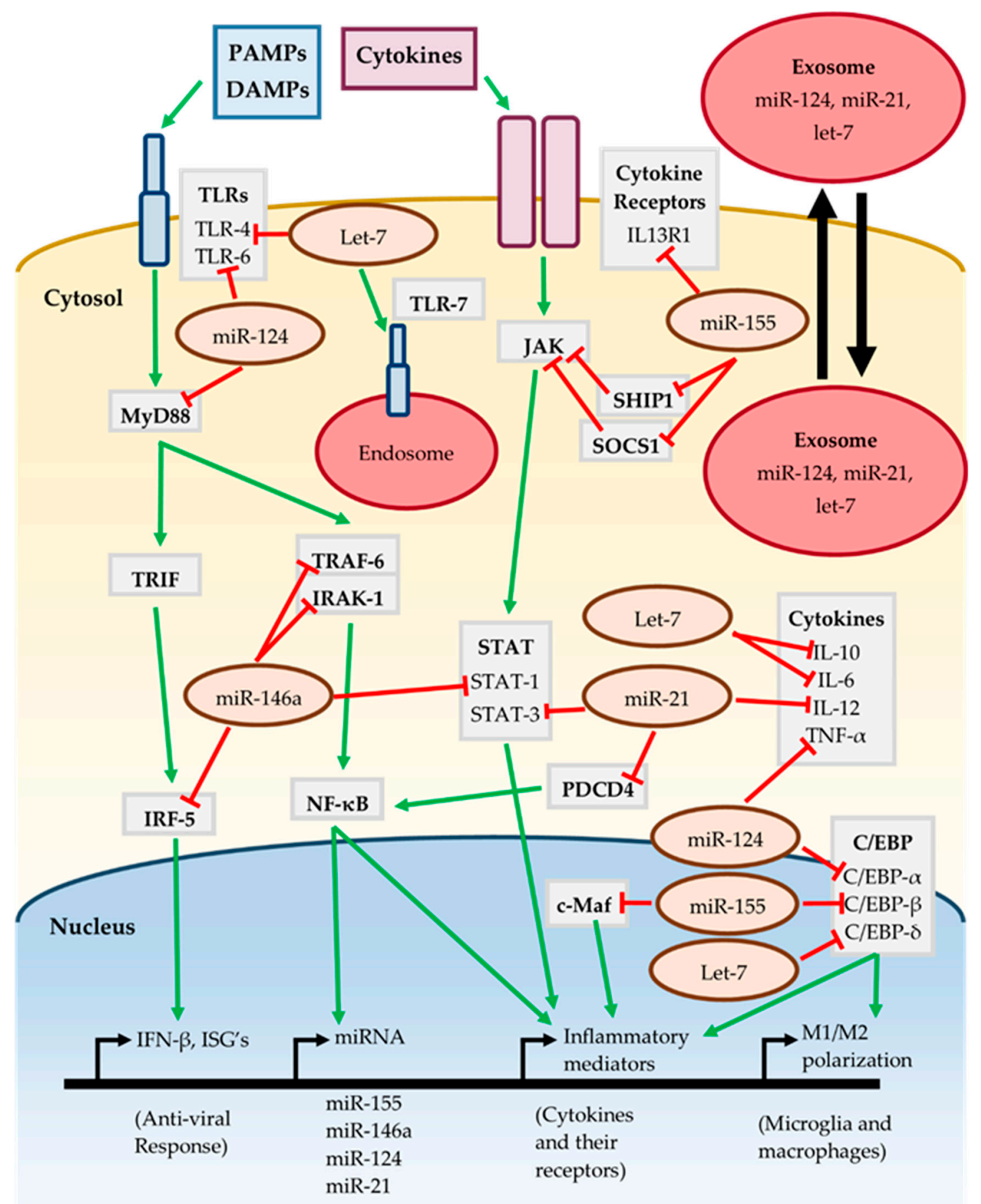

Figure 1. Inflammatory signaling of miRNA. See text for further details and references.

\section{MiRNAs in Disorders of Neuroinflammation}

MiRNAs have been implicated in the pathogenesis of a variety of neurological disorders, consistent with their proven roles in neuroinflammation. Many parallels can be drawn between the mode of regulation by miRNA in such disorders, even among such diverse pathologies as neurodegenerative diseases, viral infections of the CNS and CNS injury. 


\subsection{Neurodegenerative Diseases}

\subsubsection{Multiple Sclerosis}

Multiple sclerosis (MS) is a chronic autoimmune disease of the CNS that most often presents in young adults (20-40 years old), predominately females, and manifests as a neurodegenerative disease caused by demyelination [77]. Although its etiology remains unknown, the neurological symptoms associated with MS arise following impaired neuronal signaling. This is due to the formation of lesions in the nervous system that are associated with the loss of oligodendrocytes and myelin, astrogliosis and neuroinflammation [78]. The neuroinflammatory component of MS results from the infiltration of macrophages and autoreactive lymphocytes into the CNS following disruption of the BBB [78]. Neurodegenerative changes in addition to neuroinflammation promote the characteristic MS pathology and contribute to the progression of the disease [79]. Among the diverse molecular players that regulate neuroinflammatory processes during MS are microRNAs.

Several miRNA inflammatory regulators are overexpressed in the lesions of MS patients including miR-155, miR-146a, miR-21 and miR-326 [80]. Interestingly genetic variants of miR-146a are also associated with MS susceptibility and relapse [81,82]. However, the effects of miR-146a on inflammatory signaling during MS remain controversial: one study reported miR-146a deficient mice had reduced inflammation and demyelination [83] while another reported that delivery of miR-146a mimics to mice increased M2 microglial polarization and remyelination [84]. The activation of microglia to a pro-inflammatory state is considered to be a hallmark of MS pathology [85]. In addition to the pro-inflammatory effects of miR-155 upregulation, the activation of microglia may be mediated via downregulation of the anti-inflammatory miR-124 within microglia. This has been observed in mice with autoimmune encephalomyelitis (an experimental model of MS) [51]. Three microRNAs which are highly upregulated in active MS lesions, miR-34a, miR-155 and miR-326, each target the inhibitor of phagocytosis CD47, which may lead to enhanced myelin phagocytosis by macrophages [80]. MiR-155 may also promote neuroinflammation during MS by targeting key BBB components, leading to an increase in BBB permeability and infiltration of immune cells from the periphery [86]. The polarization of $\mathrm{T}$ cells towards different functional subsets is also known to contribute to the immunopathology of MS, and may be influenced by a number of miRNAs including miR-155, miR-146a, miR-326, miR-301a and miR-182 [87]. Therefore, regulation of inflammatory processes by miRNA plays diverse and important roles in the pathogenesis of MS.

\subsubsection{Alzheimer's Disease}

Alzheimer's Disease (AD) is the most common cause of dementia worldwide, and is a chronic and progressive neurodegenerative disorder that results from the loss of synapses and eventually, neuron death [88]. The two hallmarks of AD pathology are the buildup of extracellular plaques of aggregated amyloid beta $(A \beta)$ peptides and intracellular neurofibrillary tangles (NFTs) of hyper-phosphorylated tau [88]. The A $\beta$ plaques originate from the amyloid precursor protein (APP), which is processed into $A \beta$ peptides by a series of enzymatic cleavage steps, including cleavage by $\beta$-secretase- 1 (BACE-1) [89]. Tau is a microtubule associated protein within neurons that becomes hyperphosphorylated during AD, causing it to aggregate into paired helical filaments (PHFs), that form NFTs within neurons [90]. Neuroinflammation also contributes to much of the pathogenesis seen in AD [91].

MiRNAs are involved in many aspects of Alzheimer's disease progression including direct regulation of APP expression [92], alternative splicing of APP [93], regulation of BACE [94-96], regulation of Tau [97] and even lipid metabolism [98]. Furthermore, miRNA mediated regulation of neuroinflammatory processes also has important implications for AD pathogenesis. TREM2 is a microglial receptor important for mediating clearance of A $\beta 42$ peptides via phagocytosis in the CNS, that is targeted by miR-34a, which is upregulated during AD [99,100]. Both miR-155 and miR-146a are upregulated in the CNS during AD and contribute to regulation of the pathogenic inflammatory signaling that is seen during this disease [101,102]. The expression of miR-146a may be induced 
by $\mathrm{A} \beta 42$ resulting in the attenuation of inflammatory signaling. Therefore it may be acting in a compensatory mechanism during $\mathrm{AD}[43,103]$. The miR-181 family regulates neuroinflammatory signaling in astrocytes [104], and has been shown to be upregulated in an AD mouse model where it interfered with synaptic plasticity through targeting c-Fos and SIRT-1 [105]. The let-7 family are overexpressed and released from neurons during AD, subsequently acting as ligands for TLR7, promoting inflammation and neuronal death [72].

\subsubsection{Parkinson's Disease}

Parkinson's disease (PD) is another neurodegenerative disease of the CNS which mainly causes motor defects due to the death of dopaminergic neurons in the substantia nigra pars compacta, although other neurological symptoms may arise as the disease progresses [106]. Loss of dopaminergic neurons is the central pathological feature of PD, which is accompanied by the accumulation of inclusions within neuronal cell bodies (Lewy bodies) and processes (Lewy neurites), in addition to microgliosis [106]. Lewy bodies are aggregates of insoluble protein, the major component of which is $\alpha$-synuclein, a protein normally abundant in neurons that misfolds into conformations that confer neurotoxicity during PD [107]. The activation of microglia, which is promoted by $\alpha$-synuclein, and induction of neuroinflammation are also thought to play a critical role in the pathogenesis of PD [108]. Therefore, it is unsurprising that the influence of miRNA on neuroinflammation plays a role in PD.

Multiple miRNAs, including miR-7, miR-153, miR-34b and miR-34c are known to repress the expression of $\alpha$-synuclein, and are therefore protective by limiting its associated neurotoxicity and neuroinflammation $[109,110]$. Furthermore, miR-7 was reported to be downregulated in a mouse model of PD [111], while miR-34b and miR-34c are known to be downregulated in PD brain samples from patients [112]. It follows that downregulation of these miRNAs may result in the overexpression of $\alpha$-synuclein within neurons during the disease, conferring neurotoxicity and promoting neuroinflammation [111]. The pro-inflammatory miR-155 is upregulated during PD, and plays a central role in the inflammatory response of microglia to $\alpha$-synuclein [113]. Conversely, overexpression of miR-124 in microglia attenuates the MEKK3/NF- $\mathrm{B} B$ inflammatory pathway, limiting the pathogenesis of the disease [114].

\subsubsection{Prion Diseases}

Prion diseases $(\operatorname{PrD})$ are a group of fatal neurodegenerative diseases that arise following misfolding of the cellular prion protein $\left(\operatorname{PrP}^{\mathrm{C}}\right)$ into a disease associated conformation $\left(\mathrm{PrP}^{\mathrm{Sc}}\right)$ that is uniquely transmissible between individuals [115]. The neurological symptoms associated with the disease are due to loss of neurons, resulting in spongiform change, and are accompanied by deposits of aggregated $\mathrm{PrP}^{\mathrm{Sc}}$ and gliosis within affected regions of the brain [116]. The central pathological event behind $\operatorname{PrD}$ is the self-template directed misfolding of prions, a feature which allows them to propagate throughout the brain and cause widespread neuronal death [117]. Like the other progressive neurodegenerative disorders discussed here, pathological neuroinflammation is central to the progression of $\operatorname{PrD}[118]$.

MiR-146a is upregulated in the brain in a variety of different prion diseases, including sCJD [119,120], GSS [120] and rodent models of the disease [121-124]. Furthermore, miR-146a is induced within microglia in response to signaling by TLRs, which are also overexpressed during prion diseases [125]. Expression of miR-146a within microglia impairs activation towards a pro-inflammatory phenotype, and the overexpression of miR-146a during prion disease may therefore seek to limit excessive neuroinflammation [125]. Many other miRNAs are known to be altered within the brain during PrD, and appear to be dynamically expressed as distinct waves throughout the course of the disease $[119,123]$. Interestingly, anti-inflammatory miR-124 is upregulated at preclinical stages of the disease, but is downregulated during clinical disease $[119,123]$. Downregulation of miR-124 may therefore release microglia from quiescence at late stages of the disease and contribute to the excessive neuroinflammation seen during PrDs. 


\subsection{CNS Viral Infection}

\subsubsection{Japanese Encephalitis Virus}

Japanese encephalitis virus (JEV) is an arthropod-borne, neurotropic, positive stranded RNA Flavivirus which can cause Japanese encephalitis (JE) in humans, although is usually asymptomatic [126]. JE is a severe disease which can cause death in as many as 30\% of cases [127], and is characterized by fever, headache, vomiting and neurological symptoms such as movement disorders, paralysis and seizures [126]. Epidermal tissues are the primary site of JEV infection, following which the virus propagates by infecting circulating blood cells including monocytes and dendritic cells [128]. JEV infiltrates the CNS by crossing the BBB, either through diffusion, receptor mediated endocytosis or possibly through infection of microvascular brain endothelial cells. This ultimately leads to widespread infection of neurons and glia in the CNS and disruption of the BBB [129]. In addition to the neuronal death directly due to JEV infection of neurons, induction of uncontrolled neuroinflammation contributes to the damage within the CNS during JE [128].

miR-155 is upregulated in brain tissue during JEV infection [130] although the role it plays remains debated. One study reported that the miR-155 promoted microglial activation and neuroinflammation by targeting SHIP1 [130], while another study reported overexpression of miR-155 in a human microglial cell line suppressed replication of JEV and impaired innate immune signaling [131]. MiR-146a is another important inflammatory regulator that is upregulated within microglial cells during JEV infection [132,133]. Overexpression of miR-146a during JEV infection limits inflammation by impairing the NF- $\mathrm{kB}$ pathway, which also may promote JEV replication via downregulation of interferon-stimulated genes $[132,133]$. Conversely, the miR-34 family inhibits JEV replication via induction of the type I interferon pathway [134]. JEV can also modulate inflammatory signaling in the host by deregulating miRNAs, including miR-432 [135], miR-301a [136], miR-29b [137], miR-22 [138], miR-370 [139], miR-19b [140] and miR-15b [141].

\subsubsection{Herpes Simplex Virus Encephalitis}

Herpes simplex virus (HSV) normally establishes lytic infection in epithelial cells causing blisters or sores, and maintains a life-long latent reservoir in sensory neurons [142]. Periodic reactivation of HSV within latently infected neurons may lead to recurrent infections, although infection with HSV is usually asymptomatic [143]. Rarely, HSV causes HSV encephalitis (HSVE), which is the most common cause of sporadic encephalitis in humans and has an extremely high mortality rate of about $70 \%$ if left untreated [144]. HSVE has symptoms similar to other viral infections of the CNS, including fever, headaches, vomiting, neurological deficits and seizures [145]. Infiltration of immune cells into the CNS, BBB disruption and inflammatory signaling all drive the neuroinflammatory response during HSE, which both promotes clearance of HSV and limits viral replication while at the same time leading to cell death and pathogenic tissue damage, which underlies the severe consequences of HSVE [146].

HSV encodes several miRNAs within its own genome that work in concert with host miR-138, which is highly expressed in neurons, to promote latency by suppressing the expression of viral transcripts that are important during lytic infection $[147,148]$. In addition to these viral miRNAs, host miRNAs are deregulated during HSVE. For instance, miR-146a is upregulated within neurons during infection with HSV-1, which may contribute to viral evasion of complement by targeting CFH and promote neuropathological changes via activation of elements of the arachidonic acid cascade [149]. HSVE also leads to induction of miR-155 [150,151], which promotes, in this case, protective inflammation as miR-155 deficient mice exhibit increased viral replication and mortality [152]. Both miR-23a and miR-373 suppress the type I interferon (IFN) response by targeting IRF-1, which promotes HSV-1 replication $[153,154]$. Similarly to JEV, miR-15b was found to be upregulated within the brain during HSVE, hinting at a role for this microRNA in regulating inflammation during multiple viral encephalopathies [141,151]. Multiple members of the miR-200 and miR-182 clusters were found to be 
upregulated during HSVE, and may play a role in the pathogenesis of the infection by regulating the biosynthesis of heparin sulfate proteoglycans, which are cell entry receptors for HSV [151].

\subsection{CNS Injury}

\subsubsection{Ischemic Stroke}

Ischemic stroke results from interrupted cerebral blood flow, usually due to an obstruction of blood vessels by blood clots, which results in damage and cell death within the CNS and is often fatal causing over six million deaths each year [155]. Deprivation of blood within the CNS immediately causes tissue damage due to insufficient energy for cellular processes and excitotoxicity, followed by reperfusion which causes edema and BBB disruption [156]. Damage in surrounding regions within the brain is subsequently induced by synaptic loss and the release of pro-apoptotic and pro-inflammatory factors by the dying neurons [157]. Following reperfusion, both microglia and dying neurons release inflammatory mediators concomitant with expression of adhesion molecules by vascular endothelial cells [158]. These changes collectively promote the entry of macrophages and neutrophils into the CNS, which further mediates neuroinflammation [158].

MicroRNAs are involved in many aspects of the pathogenic mechanisms that underlie the tissue damage following stroke including excitotoxicity, oxidative stress, BBB damage and apoptosis as well as aspects of post-stroke recovery including neurogenesis and angiogenesis (see [159]). Furthermore, modulation of inflammation by miRNA following ischemia contributes to the progression of pathology. For instance, miR-210 is induced during stroke and appears to promote inflammation by upregulating the expression of pro-inflammatory cytokines and chemokines [160]. Members of the miR-181 family are also modulated following cerebral ischemia and exacerbate tissue damage by promoting neuronal death and inflammatory signaling [161-163]. The pro-inflammatory effects of miR-155 are unclear, it has been identified as downregulated following stroke [164], and inhibition of this microRNA limits inflammation and is protective $[165,166]$. Downregulation of miR-155 may reflect a mechanism to limit inflammation in some regions of the brain following ischemia. Over-expression of miR-124 was shown to be neuroprotective in a mouse model of stroke by promoting M2 microglial polarization and limiting inflammation $[167,168]$. Similarly, decreased miR-424 expression in the brain tissue of mice following ischemia is protective by suppressing microglial activation and oxidative stress $[169,170]$. Overexpression of miR-22 was also found to reduce pro-inflammatory cytokines and NF-kB activity while increasing expression of IL-10 and impairing apoptosis [171].

\subsubsection{Traumatic Brain Injury}

Traumatic brain injury (TBI) is a common cause of death and disability worldwide and may progress towards chronic brain injury [172]. Following primary injury, which results in cell death directly due to physical damage, a heterogeneous group of aberrant biochemical cascades referred to as secondary injury may follow [173]. Secondary injury leads to a series of long-term progressive changes in brain physiology that can cause seizures, sleep disorders or neurodegenerative disorders among others [174]. Several cellular processes mediate secondary injury such as excitotoxicity from increased glutamate, generation of reactive oxygen species, excessive apoptosis and neuroinflammation [174]. Activation of microglia, recruitment of immune cells into the CNS and pro-inflammatory signaling are all central processes that underlie the neuroinflammatory component of TBI [175].

One of the best studied miRNAs in TBI is miR-21, which is upregulated in brain microvascular endothelial cells [176] and in extracellular exosomes [177]. miR-21 is considered protective in TBI as it promotes BBB repair and angiogenesis while suppressing apoptosis, and may exert its anti-inflammatory effects on microglia [176-178]. miR-107 and miR-103 have been shown to be downregulated in the hippocampus following TBI [179]. These two miRNAs differ by only a single nucleotide and are similarly downregulated during AD [180] implying a related function. miR-107 targets granulin, a protein involved in wound repair, neoplasia and inflammation, and 
has been implicated in neurodegenerative diseases, therefore suggesting a mechanism by which miR-107 and miR-103 regulate inflammation and neuronal dysfunction [181,182]. The expression of miR-34a is also modulated following TBI, and may influence neuronal differentiation and proliferation by targeting the Notch pathway [183,184]. Furthermore, overexpression of miR-34a along with miR-451 and miR-874 made neurons more vulnerable to injury via increase in pro-inflammatory and pro-apoptotic factors [185]. The pro-inflammatory miR-155 in addition to miR-223 were also significantly overexpressed following TBI, and therefore may play an important role in controlling the response to injury [186]. Similarly to stroke, in vivo inhibition of miR-155 limits neuroinflammation and is protective [187].

\subsection{Notable miRNAs in Neuroinflammatory Disorders}

Some miRNAs are outstanding in that they have been implicated in many of the neuroinflammatory disorders previously discussed and are summarized in Table 1. For instance, the upregulation of miR-155 usually coincides with increased neuroinflammation which results in worsened disease severity $[86,102,113,187]$. However, in the context of viral encephalopathies such as JEV and HSVE miR-155 expression was protective and suppressed viral replication, likely by promoting clearance of virus from the CNS through its associated inflammatory signaling [131,152]. Conversely miR-146a expression dampens inflammatory signaling in a negative feedback loop. Although this may have positive consequences for neurodegenerative diseases $[43,84,125]$, the severity of viral infection in the CNS is worsened by miR-146a expression through attenuation of interferon stimulated gene (ISG) signaling and increased viral replication $[149,151]$. MiR-124 is another anti-inflammatory microRNA that is usually protective in neurodegenerative diseases and CNS injury by preventing activation of microglia to a pro-inflammatory phenotype $[51,114,121,168]$. MiR-181 may play a common role in the pathogenesis of $\mathrm{AD}$ and ischemic stroke by promoting neuronal death and inflammatory signaling [105,161,162].

Other miRNAs are notable in that they may have unique or diverging roles in neuroinflammation and are also summarized in Table 1. Although MiR-21 is known to be increased in the lesions of MS patients, a role for it in this context has yet to be determined [80]. Upregulation of miR-21 in the brain may reflect an attempt of tissue repair, as seen following traumatic brain injury $[176,177]$. The let-7 family represent a unique case as they may promote inflammation by directly acting as a DAMP for TLR-7 during AD [72]. This mode of regulation may not be unique to let-7, as miR-21 has also been shown to work as a TLR ligand [188]. MiR-34 is another example of a miRNA with diverging functions as it promotes macrophage phagocytosis in MS by targeting CD47 yet prevented microglia phagocytotic clearance of $\mathrm{A} \beta 42$ in AD by targeting TREM2 [80,99,100]. Furthermore, miR-34 targets $\alpha$-synuclein but is downregulated during PD which contributes to disease pathogenesis, whereas overexpression of miR-34 worsened traumatic brain injury by promoting apoptosis and inflammation [112,185]. Contrary to this, miR-34 is protective in viral encephalitis by inducing the type I interferon response [134]. 
Table 1. Notable miRNAs in disorders of neuroinflammation.

\begin{tabular}{|c|c|c|c|c|}
\hline miRNA & Disorder & Expression & Consequences & Reference \\
\hline \multirow{7}{*}{ miR-155 } & MS & Up & $\begin{array}{l}\text { Increased activation of microglia, enhancement of } \\
\text { phagocytosis and increased BBB permeability }\end{array}$ & {$[80,86]$} \\
\hline & $\mathrm{AD}$ & Up & Increased inflammation & [102] \\
\hline & PD & $\mathrm{Up}$ & Microglial inflammatory response & [113] \\
\hline & JEV & Up & $\begin{array}{l}\text { Microglial activation and suppression of viral } \\
\text { replication and innate immune signaling }\end{array}$ & {$[130,131]$} \\
\hline & HSVE & Up & $\begin{array}{l}\text { Protective inflammatory response and decreases } \\
\text { viral replication }\end{array}$ & [150-152] \\
\hline & Stroke & Down & Decreased inflammation and tissue damage & [164-166] \\
\hline & TBI & Up & Increased inflammation and tissue damage & {$[186,187]$} \\
\hline \multirow{5}{*}{ miR-146a } & MS & Up & $\begin{array}{l}\text { Complex, influences inflammation and } \\
\text { demyelination/remyelination }\end{array}$ & {$[80,83,84]$} \\
\hline & $\mathrm{AD}$ & Up & Attenuates inflammatory signaling & {$[43,103]$} \\
\hline & $\operatorname{PrD}$ & Up & Dampens microglial inflammatory response & [125] \\
\hline & JEV & Up & $\begin{array}{c}\text { Decreased inflammation and ISG secretion, promotes } \\
\text { JEV replication }\end{array}$ & {$[132,133]$} \\
\hline & HSVE & Up & Decreased inflammation, promotes viral replication & {$[149,151]$} \\
\hline \multirow{4}{*}{ miR-124 } & MS & Down & Release from microglial quiescence & [51] \\
\hline & PD & - & Attenuates inflammatory signaling in microglia & [114] \\
\hline & $\operatorname{PrD}$ & Up then down & Release from microglial quiescence & {$[119,123]$} \\
\hline & Stroke & - & $\begin{array}{c}\text { M2 microglial polarization, decreased inflammation, } \\
\text { protective effect }\end{array}$ & {$[167,168]$} \\
\hline \multirow{2}{*}{ miR-21 } & MS & Up & CNS specific function unknown & [80] \\
\hline & TBI & Up & $\begin{array}{l}\text { Increased BBB repair and angiogenesis, impaired } \\
\text { apoptosis and inflammation }\end{array}$ & [176-178] \\
\hline Let-7 & $\mathrm{AD}$ & Up & Acts as a DAMP for TLR-7 & [72] \\
\hline \multirow{2}{*}{ miR-181 } & $\mathrm{AD}$ & Up & Neuronal dysfunction & [105] \\
\hline & Stroke & Up & $\begin{array}{l}\text { Promotes neuronal death and inflammatory } \\
\text { signaling }\end{array}$ & [161-163] \\
\hline \multirow{5}{*}{$\operatorname{miR}-34$} & MS & Up & Enhanced macrophage phagocytosis & [80] \\
\hline & $\mathrm{AD}$ & Up & Impaired $A \beta 42$ clearance by microglia & {$[99,100]$} \\
\hline & PD & Down & $\begin{array}{l}\text { Increased } \alpha \text {-synuclein expression and increased } \\
\text { inflammation }\end{array}$ & [112] \\
\hline & JEV & - & $\begin{array}{l}\text { Induces type I interferon signaling, decreases viral } \\
\text { replication }\end{array}$ & [134] \\
\hline & TBI & - & $\begin{array}{l}\text { Promotes release of pro-inflammatory and } \\
\text { pro-apoptotic factors }\end{array}$ & [185] \\
\hline
\end{tabular}

Abbreviations: MS—Multiple Sclerosis; AD—Alzheimer's disease; PD—Parkinson's disease; PrD—Prion diseases; JEV—Japanese encephalitis virus; HSVE-Herpes simplex virus encephalitis; TBI-Traumatic brain injury; BBB — blood brain barrier; CNS - central nervous system; ISG—interferon stimulated gene; DAMP—danger associated molecular pattern; TLR—-toll like receptor.

\section{MiRNAs as Biomarkers for Neuroinflammatory Diseases}

These neurological disorders all feature pathogenic neuroinflammation and thus often exhibit similar and overlapping symptoms, which complicates diagnosis of a specific neurodegenerative disorder. For example, differential diagnosis of MS, AD and PD relies on a combination of careful clinical assessment, brain imaging techniques and detection of disease specific biomarkers such as misfolded proteins or inflammatory cytokines [189]. Identification of the cause of a viral encephalitis such as JEV or HSVE often relies on antibody or PCR based tests, or CSF blood cultures to detect the infectious agent, although this diagnosis is usually delayed several days which impedes the impact of potential treatments [190]. The diagnosis of TBI can be challenging as these disorders may originate 
from many different causes and take on different levels of severity [191]. Therefore, improved methods to diagnose and differentiate these diseases are required.

As the expression of miRNAs are commonly altered during disease, they have gained much attention for their potential use as biomarkers. It is important to note that many miRNAs are commonly altered in multiple diseases, for instance miR-155 and miR-146a that regulate inflammation in the disorders discussed previously. Some miRNAs are even commonly altered during a spectrum of many different types of disease. For example, expression of miR-155 and miR-21 are altered during cancer, diabetes and coronary artery disease in addition to neurodegenerative diseases [192]. Therefore, in order to distinguish specific pathologies on the basis of miRNA expression, patterns of multiple miRNAs that are specifically altered during the disease state must be identified.

Multiple studies have identified potential miRNA biomarkers for neuroinflammatory diseases including MS [193], AD [194], PD [194], PrDs [195], JEV [196], ischemic stroke [197] and TBI [198]. The use of miRNA as biomarkers to help diagnose these disorders offers several advantages. Not only are cellular miRNA altered during disease, but circulating miRNA in accessible biofluids such as serum or CSF are also altered and can reflect brain pathologies [192]. MiRNAs are also highly stable molecules in tissues including biofluids, therefore their detection may be more reliable than other types of circulating RNA [199]. Identification of altered miRNA signatures during these neuroinflammatory disorders may lay the groundwork towards developing better diagnostic assays which could help distinguish these often-overlapping diseases at early stages of development. Indeed, many of the inflammatory miRNAs within the CNS discussed previously have already been identified in circulating fluids such as plasma, serum, blood and CSF as biomarkers of neuroinflammatory diseases (Table 2). Therefore, it may be possible to use these miRNAs along with others in non-invasive diagnostic assays for neurological disorders.

Table 2. Inflammatory miRNAs identified as non-invasive biomarkers of neuroinflammatory disorders.

\begin{tabular}{|c|c|c|c|c|c|}
\hline Disorder & Plasma/Serum & Whole Blood & PBMCs & CSF & Reference \\
\hline MS & let-7 & miR-146b & $\begin{array}{l}\text { miR-146a, } \\
\text { miR-155 }\end{array}$ & miR-181c & [193] \\
\hline $\mathrm{AD}$ & $\begin{array}{c}\text { let-7, miR-34, } \\
\text { miR-181c, } \\
\text { miR-21 }\end{array}$ & $\begin{array}{l}\text { let-7, miR-103a, } \\
\text { miR-107 }\end{array}$ & $\begin{array}{l}\text { miR-34a, } \\
\text { miR-181b }\end{array}$ & $\begin{array}{c}\text { miR-146a, } \\
\text { miR-155, } \\
\text { miR-34a, } \\
\text { miR-124, } \\
\text { miR-181a }\end{array}$ & {$[194,200]$} \\
\hline PD & miR-181c & - & - & let-7 & {$[194,200]$} \\
\hline $\operatorname{PrD}$ & miR-21 & - & - & - & [195] \\
\hline JEV & - & - & - & $\begin{array}{c}\text { miR-21, let-7, } \\
\text { miR-181a }\end{array}$ & [196] \\
\hline Stroke & - & let-7, miR-21 & - & - & [197] \\
\hline TBI & miR-21 & - & - & miR-181 & [198] \\
\hline
\end{tabular}

Abbreviations: PBMC - peripheral blood mononuclear cell; CSF - cerebrospinal fluid; MS - Multiple Sclerosis; AD - Alzheimer's disease; PD - Parkinson's disease; PrD - Prion diseases; JEV - Japanese encephalitis virus; TBI Traumatic brain injury.

\section{Therapeutic Applications of miRNAs in Neuroinflammatory Disease}

By regulating the expression of multiple genes and pathways, miRNAs play a pivotal role in the pathogenesis of many neuroinflammatory disorders. The molecular and cellular processes that underlie the pathogenesis of these disorders are often very complex. Given the central role of miRNAs in regulating molecular cascades during health and disease they may serve as important therapeutic targets. [201]. Indeed, miRNA based therapeutics have been proposed in many complex, difficult to treat disorders such as cancer, heart disease and diabetes in addition to neuroinflammation [202]. 
The ability to control the expression of miRNA in vivo will serve as the basis for the development for miRNA therapeutics, and as such many new tools have been developed to modulate their expression. For instance, miRNA mimics are small synthetic double stranded miRNA molecules which are processed into functional miRNA, permitting the restoration of a miRNA within a cell [203]. Alternatively, miRNA expression vectors can be used to induce the expression of a specific miRNA within tissues [203]. The activity of a miRNA can also be suppressed, usually through delivery of synthetic sequences complementary to the miRNA which block its binding to endogenous mRNA targets, such as antagomirs, locked nucleic acids anti-miRs and miRNA sponges [204].

One of the main challenges towards applying these technologies in the treatment of disorders in the CNS is the delivery of miRNA-based therapeutics across the BBB. Several promising avenues are being explored which could mediate the delivery of such therapeutics. They include non-viral methods such as lipid-based or polymeric nanoparticle-based delivery systems which work to promote the cellular uptake of miRNA therapeutics $[205,206]$. Focused ultrasound is another technique which can be used to transiently disrupt the BBB, allowing for targeted delivery of therapeutics [207]. Additionally, viral vectors such as adenovirus vectors and adeno-associated virus (AAV) vectors can be used to induce the expression of a miRNA within the CNS [208]. Therefore, the identification of ideal miRNA therapeutic targets and development of efficient delivery systems to the CNS may allow for improved management and treatment of pathological neuroinflammation.

\section{Conclusions/Perspectives}

Pathological neuroinflammation is a process which underlies multiple CNS disorders. Understanding the mechanisms that lead to these inflammatory processes will undoubtedly inform the development of novel therapeutic and diagnostic strategies which could help alleviate the global burden of these disorders. MiRNAs are among the regulatory molecules capable of modulating neuroinflammatory signaling. Indeed, some miRNAs are common to multiple disorders and have been shown to play central roles in controlling inflammation. For instance, both miR-146a and miR-155 are dysregulated during many of the disorders and extensive studies have shown them to play similar roles across multiple pathologies. Other miRNAs may be disease-specific and it is the cumulative effect of the interactions between multiple miRNAs that influences the outcome of neuroinflammation during disease. MiRNAs are also found circulating in biofluids where they take on specific patterns of altered expression during neuroinflammatory disorders. Therefore, there is much potential in identifying these disease-specific patterns as part of a strategy for diagnosis, prognosis and assessing the effectiveness of therapeutic interventions. Furthermore, inducing anti-inflammatory miRNAs or suppressing pro-inflammatory miRNAs could be a therapeutic strategy to ameliorate tissue damage within the CNS following rampant neuroinflammation. Although progress has been made towards understanding the role of miRNAs in neuroinflammation many disorders remain poorly characterized, and there are a multitude of miRNAs that have roles yet to be determined.

Author Contributions: Writing—original draft preparation, J.S.; writing—review and editing, J.S. and S.B.

Funding: This research received no external funding.

Conflicts of Interest: The authors declare no conflict of interest.

\section{References}

1. Engelhardt, B.; Vajkoczy, P.; Weller, R.O. The Movers and Shapers in Immune Privilege of the CNS. Nat. Immunol. 2017, 18, 123-131. [CrossRef] [PubMed]

2. Shabab, T.; Khanabdali, R.; Moghadamtousi, S.Z.; Kadir, H.A.; Mohan, G. Neuroinflammation Pathways: A General Review. Int. J. Neurosci. 2017, 127, 624-633. [CrossRef] [PubMed]

3. Klein, R.S.; Garber, C.; Howard, N. Infectious Immunity in the Central Nervous System and Brain Function. Nat. Immunol. 2017, 18, 132-141. [CrossRef] [PubMed] 
4. Disabato, D.; Quan, N.; Godbout, J.P. Neuroinflammation: The Devil Is in the Details. J. Neurochem. 2017, 139, 136-153. [CrossRef]

5. Kempuraj, D.; Thangavel, R.; Natteru, P.A.; Selvakumar, G.P.; Saeed, D.; Zahoor, H.; Zaheer, S.; Iyer, S.S.; Zaheer, A. Neuroinflammation Induces Neurodegeneration. J. Neurol. Neurosurg. Spine 2016, 1, 1003. [CrossRef] [PubMed]

6. Wieghofer, P.; Prinz, M. Genetic Manipulation of Microglia during Brain Development and Disease. Biochim. Biophys. Acta Mol. Basis Dis. 2016, 1862, 299-309. [CrossRef]

7. Kabba, J.A.; Xu, Y.; Christian, H.; Ruan, W.; Chenai, K.; Xiang, Y.; Zhang, L.; Saavedra, J.M.; Pang, T. Microglia: Housekeeper of the Central Nervous System. Cell. Mol. Neurobiol. 2018, 38, 53-71. [CrossRef] [PubMed]

8. Harry, G.J. Microglia during Development and Aging. Pharmacol. Ther. 2013, 139, 313-326. [CrossRef]

9. Cherry, J.D.; Olschowka, J.A.; O’Banion, M. Neuroinflammation and M2 Microglia: The Good, the Bad, and the Inflamed. J. Neuroinflamm. 2014, 11, 98. [CrossRef]

10. Tang, Y.; Le, W. Differential Roles of M1 and M2 Microglia in Neurodegenerative Diseases. Mol. Neurobiol. 2016, 53, 1181-1194. [CrossRef]

11. Cekanaviciute, E.; Buckwalter, M.S. Astrocytes: Integrative Regulators of Neuroinflammation in Stroke and Other Neurological Diseases. Neurotherapeutics 2016, 13, 685-701. [CrossRef]

12. Vasile, F.; Dossi, E.; Rouach, N. Human Astrocytes: Structure and Functions in the Healthy Brain. Brain Struct. Funct. 2017, 222, 2017-2029. [CrossRef]

13. Dossi, E.; Vasile, F.; Rouach, N. Human Astrocytes in the Diseased Brain. Brain Res. Bull. 2018, 136, $139-156$. [CrossRef] [PubMed]

14. Sofroniew, M.V. Astrocyte Barriers to Neurotoxic Inflammation. Nat. Rev. Neurosci. 2015, 16, $249-263$. [CrossRef]

15. Tohidpour, A.; Morgun, A.V.; Boitsova, E.B.; Malinovskaya, N.A.; Martynova, G.P.; Khilazheva, E.D.; Kopylevich, N.V.; Gertsog, G.E.; Salmina, A.B. Neuroinflammation and Infection: Molecular Mechanisms Associated with Dysfunction of Neurovascular Unit. Front. Cell. Infect. Microbiol. 2017, 7, 276. [CrossRef]

16. Muoio, V.; Persson, P.B.; Sendeski, M.M. The Neurovascular Unit-Concept Review. Acta Physiol. 2014, 210, 790-798. [CrossRef]

17. Iadecola, C. The Neurovascular Unit Coming of Age: A Journey through Neurovascular Coupling in Health and Disease. Neuron 2017, 96, 17-42. [CrossRef] [PubMed]

18. Presta, I.; Vismara, M.; Novellino, F.; Donato, A.; Zaffino, P.; Scali, E.; Pirrone, K.C.; Spadea, M.F.; Malara, N.; Donato, G. Innate Immunity Cells and the Neurovascular Unit. Int. J. Mol. Sci. 2018, 19, 3856. [CrossRef] [PubMed]

19. Carthew, R.W.; Sontheimer, E.J. Origins and Mechanisms of MiRNAs and SiRNAs. Cell 2009, 136, $642-655$. [CrossRef]

20. Ha, M.; Kim, V.N. Regulation of MicroRNA Biogenesis. Nat. Rev. Mol. Cell Biol. 2014, 15, 509-524. [CrossRef] [PubMed]

21. Borchert, G.M.; Lanier, W.; Davidson, B.L. RNA Polymerase III Transcribes Human MicroRNAs. Nat. Struct. Mol. Biol. 2006, 13, 1097-1101. [CrossRef] [PubMed]

22. Macias, S.; Cordiner, R.A.; Cáceres, J.F. Cellular Functions of the Microprocessor. Biochem. Soc. Trans. 2013, 41, 838-843. [CrossRef] [PubMed]

23. Song, M.-S.; Rossi, J.J. Molecular Mechanisms of Dicer: Endonuclease and Enzymatic Activity. Biochem. J. 2017, 474, 1603-1618. [CrossRef] [PubMed]

24. Wilson, R.C.; Doudna, J.A. Molecular Mechanisms of RNA Interference. Annu. Rev. Biophys. 2013, 42, 217-239. [CrossRef]

25. Meijer, H.A.; Smith, E.M.; Bushell, M. Regulation of MiRNA Strand Selection: Follow the Leader? Biochem. Soc. Trans. 2014, 42, 1135-1140. [CrossRef]

26. Gorski, S.A.; Vogel, J.; Doudna, J.A. RNA-Based Recognition and Targeting: Sowing the Seeds of Specificity. Nat. Rev. Mol. Cell Biol. 2017, 18, 215-228. [CrossRef] [PubMed]

27. Park, J.H.; Shin, C. MicroRNA-Directed Cleavage of Targets: Mechanism and Experimental Approaches. BMB Rep. 2014, 47, 417-423. [CrossRef]

28. Fabian, M.R.; Sonenberg, N.; Filipowicz, W. Regulation of MRNA Translation and Stability by MicroRNAs. Annu. Rev. Biochem. 2010, 79, 351-379. [CrossRef] 
29. Friedman, R.C.; Farh, K.K.H.; Burge, C.B.; Bartel, D.P. Most Mammalian MRNAs Are Conserved Targets of MicroRNAs. Genome Res. 2009, 19, 92-105. [CrossRef]

30. Kozomara, A.; Birgaoanu, M.; Griffiths-Jones, S. MiRBase: From MicroRNA Sequences to Function. Nucleic Acids Res. 2019, 47, D155-D162. [CrossRef]

31. Helwak, A.; Kudla, G.; Dudnakova, T.; Tollervey, D. Mapping the Human MiRNA Interactome by CLASH Reveals Frequent Noncanonical Binding. Cell 2013, 153, 654-665. [CrossRef]

32. Bayraktar, R.; Van Roosbroeck, K.; Calin, G.A. Cell-to-Cell Communication: MicroRNAs as Hormones. Mol. Oncol. 2017, 11, 1673-1686. [CrossRef]

33. Vishnoi, A.; Rani, S. MiRNA Biogenesis and Regulation of Diseases: An Overview. In Methods in Molecular Biology; Springer: Berlin, Germany, 2017; Volume 1509, pp. 1-10. [CrossRef]

34. Wang, P.; Hou, J.; Lin, L.; Wang, C.; Liu, X.; Li, D.; Ma, F.; Wang, Z.; Cao, X. Inducible MicroRNA-155 Feedback Promotes Type I IFN Signaling in Antiviral Innate Immunity by Targeting Suppressor of Cytokine Signaling 1. J. Immunol. 2010, 185, 6226-6233. [CrossRef]

35. Bala, S.; Marcos, M.; Kodys, K.; Csak, T.; Catalano, D.; Mandrekar, P.; Szabo, G. Up-Regulation of MicroRNA-155 in Macrophages Contributes to Increased Tumor Necrosis Factor $\alpha$ (TNF $\alpha$ ) Production via Increased MRNA Half-Life in Alcoholic Liver Disease. J. Biol. Chem. 2011, 286, 1436-1444. [CrossRef] [PubMed]

36. Cardoso, A.L.; Guedes, J.R.; Pereira de Almeida, L.; Pedroso de Lima, M.C. MiR-155 Modulates Microglia-Mediated Immune Response by down-Regulating SOCS-1 and Promoting Cytokine and Nitric Oxide Production. Immunology 2012, 135, 73-88. [CrossRef]

37. O'Connell, R.M.; Taganov, K.D.; Boldin, M.P.; Cheng, G.; Baltimore, D. MicroRNA-155 Is Induced during the Macrophage Inflammatory Response. Proc. Natl. Acad. Sci. USA 2007, 104, 1604-1609. [CrossRef] [PubMed]

38. O'Connell, R.M.; Chaudhuri, A.A.; Rao, D.S.; Baltimore, D. Inositol Phosphatase SHIP1 Is a Primary Target of MiR-155. Proc. Natl. Acad. Sci. USA 2009, 106, 7113-7118. [CrossRef]

39. Worm, J.; Stenvang, J.; Petri, A.; Frederiksen, K.S.; Obad, S.; Elmén, J.; Hedtjärn, M.; Straarup, E.M.; Hansen, J.B.; Kauppinen, S. Silencing of MicroRNA-155 in Mice during Acute Inflammatory Response Leads to Derepression of c/Ebp Beta and down-Regulation of G-CSF. Nucleic Acids Res. 2009, 37, 5784-5792. [CrossRef] [PubMed]

40. Martinez-Nunez, R.T.; Louafi, F.; Sanchez-Elsner, T. The Interleukin 13 (IL-13) Pathway in Human Macrophages Is Modulated by MicroRNA-155 via Direct Targeting of Interleukin 13 Receptor A1 (IL13R $\alpha 1$ ). J. Biol. Chem. 2011, 286, 1786-1794. [CrossRef]

41. Su, W.; Hopkins, S.; Nesser, N.K.; Sopher, B.; Silvestroni, A.; Ammanuel, S.; Jayadev, S.; Moller, T.; Weinstein, J.; Garden, G.A. The P53 Transcription Factor Modulates Microglia Behavior through MicroRNA-Dependent Regulation of c-Maf. J. Immunol. 2014, 192, 358-366. [CrossRef] [PubMed]

42. Taganov, K.D.; Boldin, M.P.; Chang, K.-J.; Baltimore, D. NF-B-Dependent Induction of MicroRNA MiR-146, an Inhibitor Targeted to Signaling Proteins of Innate Immune Responses. Proc. Natl. Acad. Sci. USA 2006, 103, 12481-12486. [CrossRef]

43. Cui, J.G.; Li, Y.Y.; Zhao, Y.; Bhattacharjee, S.; Lukiw, W.J. Differential Regulation of Interleukin-1 Receptor-Associated Kinase-1 (IRAK-1) and IRAK-2 by MicroRNA-146a and NF-KB in Stressed Human Astroglial Cells and in Alzheimer Disease. J. Biol. Chem. 2010, 285, 38951-38960. [CrossRef] [PubMed]

44. Li, Y.Y.; Cui, J.G.; Dua, P.; Pogue, A.I.; Bhattacharjee, S.; Lukiw, W.J. Differential Expression of MiRNA-146a-Regulated Inflammatory Genes in Human Primary Neural, Astroglial and Microglial Cells. Neurosci. Lett. 2011, 499, 109-113. [CrossRef] [PubMed]

45. Wu, D.; Cerutti, C.; Lopez-Ramirez, M.A.; Pryce, G.; King-Robson, J.; Simpson, J.E.; Van Der Pol, S.M.A.; Hirst, M.C.; De Vries, H.E.; Sharrack, B.; et al. Brain Endothelial MiR-146a Negatively Modulates T-Cell Adhesion through Repressing Multiple Targets to Inhibit NF-KB Activation. J. Cereb. Blood Flow Metab. 2015, 35, 412-423. [CrossRef]

46. He, X.; Tang, R.; Sun, Y.; Wang, Y.-G.; Zhen, K.-Y.; Zhang, D.-M.; Pan, W.-Q. MicroR-146 Blocks the Activation of M1 Macrophage by Targeting Signal Transducer and Activator of Transcription 1 in Hepatic Schistosomiasis. EBioMedicine 2016, 13, 339-347. [CrossRef]

47. Tang, Y.; Luo, X.; Cui, H.; Ni, X.; Yuan, M.; Guo, Y.; Huang, X.; Zhou, H.; De Vries, N.; Tak, P.P.; et al. MicroRNA-146a Contributes to Abnormal Activation of the Type I Interferon Pathway in Human Lupus by Targeting the Key Signaling Proteins. Arthritis Rheum. 2009, 60, 1065-1075. [CrossRef] 
48. Lukiw, W.J.; Zhao, Y.; Jian, G.C. An NF-KB-Sensitive Micro RNA-146a-Mediated Inflammatory Circuit in Alzheimer Disease and in Stressed Human Brain Cells. J. Biol. Chem. 2008, 283, 31315-31322. [CrossRef] [PubMed]

49. Huang, C.; Liu, X.; QunZhou; Xie, J.; Ma, T.; Meng, X.; Li, J. MiR-146a Modulates Macrophage Polarization by Inhibiting Notch1 Pathway in RAW264.7 Macrophages. Int. Immunopharmacol. 2016, 32, 46-54. [CrossRef] [PubMed]

50. Makeyev, E.V.; Zhang, J.; Carrasco, M.A.; Maniatis, T. The MicroRNA MiR-124 Promotes Neuronal Differentiation by Triggering Brain-Specific Alternative Pre-MRNA Splicing. Mol. Cell 2007, 27, 435-448. [CrossRef] [PubMed]

51. Ponomarev, E.D.; Veremeyko, T.; Barteneva, N.; Krichevsky, A.M.; Weiner, H.L. MicroRNA-124 Promotes Microglia Quiescence and Suppresses EAE by Deactivating Macrophages via the C/EBP- $\alpha$-PU.1 Pathway. Nat. Med. 2011, 17, 64-70. [CrossRef] [PubMed]

52. Veremeyko, T.; Siddiqui, S.; Sotnikov, I.; Yung, A.; Ponomarev, E.D. IL-4/IL-13-Dependent and Independent Expression of MiR-124 and Its Contribution to M2 Phenotype of Monocytic Cells in Normal Conditions and during Allergic Inflammation. PLoS ONE 2013, 8, e81774. [CrossRef] [PubMed]

53. Ma, C.; Li, Y.; Li, M.; Deng, G.; Wu, X.; Zeng, J.; Hao, X.; Wang, X.; Liu, J.; Cho, W.C.S.; et al. MicroRNA-124 Negatively Regulates TLR Signaling in Alveolar Macrophages in Response to Mycobacterial Infection. Mol. Immunol. 2014, 62, 150-158. [CrossRef]

54. Louw, A.M.; Kolar, M.K.; Novikova, L.N.; Kingham, P.J.; Wiberg, M.; Kjems, J.; Novikov, L.N. Chitosan Polyplex Mediated Delivery of MiRNA-124 Reduces Activation of Microglial Cells in Vitro and in Rat Models of Spinal Cord Injury. Nanomed. Nanotechnol. Biol. Med. 2016, 12, 643-653. [CrossRef] [PubMed]

55. Freilich, R.W.; Woodbury, M.E.; Ikezu, T. Integrated Expression Profiles of MRNA and MiRNA in Polarized Primary Murine Microglia. PLoS ONE 2013, 8, e79416. [CrossRef] [PubMed]

56. Sheedy, F.J. Turning 21: Induction of MiR-21 as a Key Switch in the Inflammatory Response. Front. Immunol. 2015, 6, 1-9. [CrossRef]

57. Zhang, L.; Dong, L.Y.; Li, Y.J.; Hong, Z.; Wei, W.S. MiR-21 Represses FasL in Microglia and Protects against Microglia-Mediated Neuronal Cell Death Following Hypoxia/Ischemia. Glia 2012, 60, 1888-1895. [CrossRef] [PubMed]

58. Li, H.-J.; Pan, Y.-B.; Sun, Z.-L.; Sun, Y.-Y.; Yang, X.-T.; Feng, D.-F. Inhibition of MiR-21 Ameliorates Excessive Astrocyte Activation and Promotes Axon Regeneration Following Optic Nerve Crush. Neuropharmacology 2018, 137, 33-49. [CrossRef]

59. Han, Z.; Chen, F.; Ge, X.; Tan, J.; Lei, P.; Zhang, J. MiR-21 Alleviated Apoptosis of Cortical Neurons through Promoting PTEN-Akt Signaling Pathway in Vitro after Experimental Traumatic Brain Injury. Brain Res. 2014, 1582, 12-20. [CrossRef]

60. Miguel-Hidalgo, J.J.; Hall, K.O.; Bonner, H.; Roller, A.M.; Syed, M.; Park, C.J.; Ball, J.P.; Rothenberg, M.E.; Stockmeier, C.A.; Romero, D.G. MicroRNA-21: Expression in Oligodendrocytes and Correlation with Low Myelin MRNAs in Depression and Alcoholism. Prog. Neuro-Psychopharmacol. Biol. Psychiatry 2017, 79, 503-514. [CrossRef]

61. Sheedy, F.J.; Palsson-Mcdermott, E.; Hennessy, E.J.; Martin, C.; O’Leary, J.J.; Ruan, Q.; Johnson, D.S.; Chen, Y.; O'Neill, L.A.J. Negative Regulation of TLR4 via Targeting of the Proinflammatory Tumor Suppressor PDCD4 by the MicroRNA MiR-21. Nat. Immunol. 2010,11, 141-147. [CrossRef]

62. Barnett, R.E.; Conklin, D.J.; Ryan, L.; Keskey, R.C.; Ramjee, V.; Sepulveda, E.A.; Srivastava, S.; Bhatnagar, A.; Cheadle, W.G. Anti-Inflammatory Effects of MiR-21 in the Macrophage Response to Peritonitis. J. Leukoc. Biol. 2015, 99, 361-371. [CrossRef]

63. Sen, C.K.; Das, A.; Khanna, S.; Roy, S.; Ganesh, K. Engulfment of Apoptotic Cells by Macrophages: A Role of MicroRNA-21 in the Resolution of Wound Inflammation. J. Immunol. 2014, 192, 1120-1129. [CrossRef]

64. Wang, Z.; Brandt, S.; Medeiros, A.; Wang, S.; Wu, H.; Dent, A.; Serezani, C.H. MicroRNA 21 Is a Homeostatic Regulator of Macrophage Polarization and Prevents Prostaglandin E2 -Mediated M2 Generation. PLoS ONE 2015, 10, e0115855. [CrossRef] [PubMed]

65. Gruner, K.; Sahni, V.; Pan, L.; McGuire, T.L.; Bhalala, O.G.; Kessler, J.A.; Tourtellotte, W.G. MicroRNA-21 Regulates Astrocytic Response Following Spinal Cord Injury. J. Neurosci. 2012, 32, 17935-17947. [CrossRef]

66. Lee, H.; Han, S.; Kwon, C.S.; Lee, D. Biogenesis and Regulation of the Let-7 MiRNAs and Their Functional Implications. Protein Cell 2016, 7, 100-113. [CrossRef] [PubMed] 
67. Tan, Z.; Yang, S.; Liu, G.; Xie, N.; Icyuz, M.; Abraham, E.; Cui, H.; Banerjee, S. MicroRNA Let-7c Regulates Macrophage Polarization. J. Immunol. 2013, 190, 6542-6549. [CrossRef]

68. Cho, K.J.; Song, J.; Oh, Y.; Lee, J.E. MicroRNA-Let-7a Regulates the Function of Microglia in Inflammation. Mol. Cell. Neurosci. 2015, 68, 167-176. [CrossRef]

69. Schulte, L.N.; Eulalio, A.; Mollenkopf, H.J.; Reinhardt, R.; Vogel, J. Analysis of the Host MicroRNA Response to Salmonella Uncovers the Control of Major Cytokines by the Let-7 Family. EMBO J. 2011, 30, 1977-1989. [CrossRef]

70. Teng, G.G.; Wang, W.H.; Dai, Y.; Wang, S.J.; Chu, Y.X.; Li, J. Let-7b Is Involved in the Inflammation and Immune Responses Associated with Helicobacter Pylori Infection by Targeting Toll-Like Receptor 4. PLoS ONE 2013, 8, e56709. [CrossRef]

71. Shenoy, A.; Danial, M.; Blelloch, R.H. Let-7 and MiR-125 Cooperate to Prime Progenitors for Astrogliogenesis. EMBO J. 2015, 34, 1180-1194. [CrossRef]

72. Lehmann, S.M.; Krüger, C.; Park, B.; Derkow, K.; Rosenberger, K.; Baumgart, J.; Trimbuch, T.; Eom, G.; Hinz, M.; Kaul, D.; et al. An Unconventional Role for MiRNA: Let-7 Activates Toll-like Receptor 7 and Causes Neurodegeneration. Nat. Neurosci. 2012, 15, 827-835. [CrossRef] [PubMed]

73. Coleman, L.G.; Zou, J.; Crews, F.T. Microglial-Derived MiRNA Let-7 and HMGB1 Contribute to Ethanol-Induced Neurotoxicity via TLR7. J. Neuroinflamm. 2017, 14, 22. [CrossRef] [PubMed]

74. Morton, M.C.; Neckles, V.N.; Seluzicki, C.M.; Holmberg, J.C.; Feliciano, D.M. Neonatal Subventricular Zone Neural Stem Cells Release Extracellular Vesicles That Act as a Microglial Morphogen. Cell Rep. 2018, 23, 78-89. [CrossRef] [PubMed]

75. Pinto, S.; Cunha, C.; Barbosa, M.; Vaz, A.R.; Brites, D. Exosomes from NSC-34 Cells Transfected with HSOD1-G93A Are Enriched in MiR-124 and Drive Alterations in Microglia Phenotype. Front. Neurosci. 2017, 11. [CrossRef] [PubMed]

76. Simeoli, R.; Montague, K.; Jones, H.R.; Castaldi, L.; Chambers, D.; Kelleher, J.H.; Vacca, V.; Pitcher, T.; Grist, J.; Al-Ahdal, H.; et al. Exosomal Cargo Including MicroRNA Regulates Sensory Neuron to Macrophage Communication after Nerve Trauma. Nat. Commun. 2017, 8, 1778. [CrossRef] [PubMed]

77. Vidal-Jordana, A.; Montalban, X. Multiple Sclerosis: Epidemiologic, Clinical, and Therapeutic Aspects. Neuroimaging Clin. N. Am. 2017, 27, 195-204. [CrossRef] [PubMed]

78. Dendrou, C.A.; Fugger, L.; Friese, M.A. Immunopathology of Multiple Sclerosis. Nat. Rev. Immunol. 2015, 15, 545-558. [CrossRef]

79. Friese, M.A.; Schattling, B.; Fugger, L. Mechanisms of Neurodegeneration and Axonal Dysfunction in Multiple Sclerosis. Nat. Rev. Neurol. 2014, 10, 225-238. [CrossRef]

80. Junker, A.; Krumbholz, M.; Eisele, S.; Mohan, H.; Augstein, F.; Bittner, R.; Lassmann, H.; Wekerle, H.; Hohlfeld, R.; Meinl, E. MicroRNA Profiling of Multiple Sclerosis Lesions Identifies Modulators of the Regulatory Protein CD47. Brain 2009, 132, 3342-3352. [CrossRef]

81. Zhou, Y.; Chen, M.; Simpson, S.; Lucas, R.M.; Charlesworth, J.C.; Blackburn, N.; van der Mei, I.; Ponsonby, A.-L.; Taylor, B.V. Common Genetic Variation within MiR-146a Predicts Disease Onset and Relapse in Multiple Sclerosis. Neurol. Sci. 2018, 39, 297-304. [CrossRef]

82. Park, R.; Lee, W.J.; Ji, J.D. Association between the Three Functional MiR-146a Single-Nucleotide Polymorphisms, Rs2910164, Rs57095329, and Rs2431697, and Autoimmune Disease Susceptibility: A Meta-Analysis. Autoimmunity 2016, 49, 451-458. [CrossRef]

83. Martin, N.A.; Molnar, V.; Szilagyi, G.T.; Elkjaer, M.L.; Nawrocki, A.; Okarmus, J.; Wlodarczyk, A.; Thygesen, E.K.; Palkovits, M.; Gallyas, F.; et al. Experimental Demyelination and Axonal Loss Are Reduced in MicroRNA-146a Deficient Mice. Front. Immunol. 2018, 9, 490. [CrossRef]

84. Zhang, J.; Zhang, Z.G.; Lu, M.; Zhang, Y.; Shang, X.; Chopp, M. MiR-146a Promotes Oligodendrocyte Progenitor Cell Differentiation and Enhances Remyelination in a Model of Experimental Autoimmune Encephalomyelitis. Neurobiol. Dis. 2019, 125, 154-162. [CrossRef]

85. Goldmann, T.; Prinz, M. Role of Microglia in CNS Autoimmunity. Clin. Dev. Immunol. 2013, $2013,1-8$. [CrossRef] [PubMed]

86. Lopez-Ramirez, M.A.; Wu, D.; Pryce, G.; Simpson, J.E.; Reijerkerk, A.; King-Robson, J.; Kay, O.; De Vries, H.E.; Hirst, M.C.; Sharrack, B.; et al. MicroRNA-155 Negatively Affects Blood-Brain Barrier Function during Neuroinflammation. FASEB J. 2014, 28, 2551-2565. [CrossRef] [PubMed] 
87. Ksiazek-Winiarek, D.J.; Kacperska, M.J.; Glabinski, A. MicroRNAs as Novel Regulators of Neuroinflammation. Med. Inflamm. 2013, 2013, 1-11. [CrossRef] [PubMed]

88. Lane, C.A.; Hardy, J.; Schott, J.M. Alzheimer's Disease. Eur. J. Neurol. 2018, 25, 59-70. [CrossRef]

89. Wilkins, H.M.; Swerdlow, R.H. Amyloid Precursor Protein Processing and Bioenergetics. Brain Res. Bull. 2017, 133, 71-79. [CrossRef]

90. Iqbal, K.; Liu, F.; Gong, C.X. Tau and Neurodegenerative Disease: The Story so Far. Nat. Rev. Neurol. 2016, 12, 15-27. [CrossRef]

91. Heneka, M.T.; Carson, M.J.; El Khoury, J.; Landreth, G.E.; Brosseron, F.; Feinstein, D.L.; Jacobs, A.H.; Wyss-Coray, T.; Vitorica, J.; Ransohoff, R.M.; et al. Neuroinflammation in Alzheimer's Disease. Lancet Neurol. 2015, 14, 388-405. [CrossRef]

92. Delay, C.; Calon, F.; Mathews, P.; Hébert, S.S. Alzheimer-Specific Variants in the 3'UTR of Amyloid Precursor Protein Affect MicroRNA Function. Mol. Neurodegener. 2011, 6, 70. [CrossRef]

93. Smith, P.; Al Hashimi, A.; Girard, J.; Delay, C.; Hébert, S.S. In Vivo Regulation of Amyloid Precursor Protein Neuronal Splicing by MicroRNAs. J. Neurochem. 2011, 116, 240-247. [CrossRef]

94. Hébert, S.S.; Horré, K.; Nicolaï, L.; Papadopoulou, A.S.; Mandemakers, W.; Silahtaroglu, A.N.; Kauppinen, S.; Delacourte, A.; De Strooper, B. Loss of MicroRNA Cluster MiR-29a/b-1 in Sporadic Alzheimer's Disease Correlates with Increased BACE1/Beta-Secretase Expression. Proc. Natl. Acad. Sci. USA 2008, 205, 6415-6420. [CrossRef]

95. Zhu, H.C.; Wang, L.M.; Wang, M.; Song, B.; Tan, S.; Teng, J.F.; Duan, D.X. MicroRNA-195 Downregulates Alzheimer's Disease Amyloid- $\beta$ Production by Targeting BACE1. Brain Res. Bull. 2012, 88, 596-601. [CrossRef]

96. Wang, W.-X.; Rajeev, B.W.; Stromberg, A.J.; Ren, N.; Tang, G.; Huang, Q.; Rigoutsos, I.; Nelson, P.T. The Expression of MicroRNA MiR-107 Decreases Early in Alzheimer's Disease and May Accelerate Disease Progression through Regulation of -Site Amyloid Precursor Protein-Cleaving Enzyme 1. J. Neurosci. 2008, 28, 1213-1223. [CrossRef]

97. Zhao, J.; Yue, D.; Zhou, Y.; Jia, L.; Wang, H.; Guo, M.; Xu, H.; Chen, C.; Zhang, J.; Xu, L. The Role of MicroRNAs in A $\beta$ Deposition and Tau Phosphorylation in Alzheimer's Disease. Front. Neurol. 2017, 8, 1-7. [CrossRef]

98. Goedeke, L.; Fernández-Hernando, C. MicroRNAs: A Connection between Cholesterol Metabolism and Neurodegeneration. Neurobiol. Dis. 2014, 72, 48-53. [CrossRef]

99. Bhattacharjee, S.; Zhao, Y.; Lukiw, W.J. Deficits in the MiRNA-34a-Regulated Endogenous TREM2 Phagocytosis Sensor-Receptor in Alzheimer's Disease (AD); an Update. Front. Aging Neurosci. 2014, 6. [CrossRef]

100. Bhattacharjee, S.; Zhao, Y.; Dua, P.; Rogaev, E.I.; Lukiw, W.J. MicroRNA-34 $\alpha$-Mediated down-Regulation of the Microglial-Enriched Triggering Receptor and Phagocytosis-Sensor TREM2 in Age-Related Macular Degeneration. PLoS ONE 2016, 11, e0150211. [CrossRef]

101. Alexandrov, P.N.; Dua, P.; Lukiw, W.J. Up-Regulation of MiRNA-146a in Progressive, Age-Related Inflammatory Neurodegenerative Disorders of the Human CNS. Front. Neurol. 2014, 5. [CrossRef]

102. Guedes, J.R.; Custódia, C.M.; Silva, R.J.; de Almeida, L.P.; de Lima, M.C.P.; Cardoso, A.L. Early MiR-155 Upregulation Contributes to Neuroinflammation in Alzheimer's Disease Triple Transgenic Mouse Model. Hum. Mol. Genet. 2014, 23, 6286-6301. [CrossRef] [PubMed]

103. Lukiw, W.J.; Alexandrov, P.N. Regulation of Complement Factor H (CFH) by Multiple MiRNAs in Alzheimer's Disease (AD) Brain. Mol. Neurobiol. 2012, 46, 11-19. [CrossRef]

104. Hutchison, E.R.; Kawamoto, E.M.; Taub, D.D.; Lal, A.; Abdelmohsen, K.; Zhang, Y.; Wood, W.H.; Lehrmann, E.; Camandola, S.; Becker, K.G.; et al. Evidence for MiR-181 Involvement in Neuroinflammatory Responses of Astrocytes. Glia 2013, 61, 1018-1028. [CrossRef] [PubMed]

105. Rodriguez-Ortiz, C.J.; Baglietto-Vargas, D.; Martinez-Coria, H.; LaFerla, F.M.; Kitazawa, M. Upregulation of MiR-181 Decreases c-Fos and SIRT-1 in the Hippocampus of 3xTg-AD Mice. J. Alzheimer's Dis. 2014, 42, 1229-1238. [CrossRef]

106. Lees, A.J.; Hardy, J.; Revesz, T. Parkinson's Disease. Lancet 2009, 373, 2055-2066. [CrossRef]

107. Kalia, L.V.; Kalia, S.K. $\alpha$-Synuclein and Lewy Pathology in Parkinson's Disease. Curr. Opin. Neurol. 2015, 28, 375-381. [CrossRef] 
108. Surendranathan, A.; Rowe, J.B.; O’Brien, J.T. Neuroinflammation in Lewy Body Dementia. Park. Relat. Disord. 2015, 21, 1398-1406. [CrossRef] [PubMed]

109. Fragkouli, A.; Doxakis, E. MiR-7 and MiR-153 Protect Neurons against MPP+-Induced Cell Death via Upregulation of MTOR Pathway. Front. Cell. Neurosci. 2014, 8, 182. [CrossRef]

110. Kabaria, S.; Choi, D.C.; Chaudhuri, A.D.; Mouradian, M.M.; Junn, E. Inhibition of MiR-34b and MiR-34c Enhances $\alpha$-Synuclein Expression in Parkinson's Disease. FEBS Lett. 2015, 589, 319-325. [CrossRef]

111. Junn, E.; Lee, K.-W.; Jeong, B.S.; Chan, T.W.; Im, J.-Y.; Mouradian, M.M. Repression of Alpha-Synuclein Expression and Toxicity by MicroRNA-7. Proc. Natl. Acad. Sci. USA 2009, 106, 13052-13057. [CrossRef]

112. Miñones-Moyano, E.; Porta, S.; Escaramís, G.; Rabionet, R.; Iraola, S.; Kagerbauer, B.; Espinosa-Parrilla, Y.; Ferrer, I.; Estivill, X.; Martí, E. MicroRNA Profiling of Parkinson's Disease Brains Identifies Early Downregulation of MiR-34b/c Which Modulate Mitochondrial Function. Hum. Mol. Genet. 2011, 20, 3067-3078. [CrossRef] [PubMed]

113. Thome, A.D.; Harms, A.S.; Volpicelli-Daley, L.A.; Standaert, D.G. MicroRNA-155 Regulates Alpha-Synuclein-Induced Inflammatory Responses in Models of Parkinson Disease. J. Neurosci. 2016, 36, 2383-2390. [CrossRef] [PubMed]

114. Yao, L.; Ye, Y.; Mao, H.; Lu, F.; He, X.; Lu, G.; Zhang, S. MicroRNA-124 Regulates the Expression of MEKK3 in the Inflammatory Pathogenesis of Parkinson's Disease. J. Neuroinflamm. 2018, 15, 13. [CrossRef] [PubMed]

115. Whitechurch, B.C.; Welton, J.M.; Collins, S.J.; Lawson, V.A. Prion Diseases. In Neurodegenerative Diseases, Advances in Neurobiology; Springer: Cham, Switzerland, 2017; pp. 335-364. [CrossRef]

116. Hughes, D.; Halliday, M. What Is Our Current Understanding of PrPSc-Associated Neurotoxicity and Its Molecular Underpinnings? Pathogens 2017, 6, 63. [CrossRef]

117. Mabbott, N. How Do PrPSc Prions Spread between Host Species, and within Hosts? Pathogens 2017, 6, 60. [CrossRef]

118. Carroll, J.A.; Chesebro, B. Neuroinflammation, Microglia, and Cell-Association during Prion Disease. Viruses 2019, 11, 65. [CrossRef]

119. Llorens, F.; Thüne, K.; Martí, E.; Kanata, E.; Dafou, D.; Díaz-Lucena, D.; Vivancos, A.; Shomroni, O.; Zafar, S.; Schmitz, M.; et al. Regional and Subtype-Dependent MiRNA Signatures in Sporadic Creutzfeldt-Jakob Disease Are Accompanied by Alterations in MiRNA Silencing Machinery and Biogenesis. PLoS Pathog. 2018, 14, e1006802. [CrossRef]

120. Lukiw, W.J.; Dua, P.; Pogue, A.I.; Eicken, C.; Hill, J.M. Upregulation of Micro RNA-146a (MiRNA-146a), A Marker for Inflammatory Neurodegeneration, in Sporadic Creutzfeldt-Jakob Disease (SCJD) and Gerstmann-Straussler-Scheinker (GSS) Syndrome. J. Toxicol. Environ. Heal. Part A 2011, 74, 1460-1468. [CrossRef]

121. Gao, C.; Wei, J.; Zhang, B.Y.; Shi, Q.; Chen, C.; Wang, J.; Shi, Q.; Dong, X.P. MiRNA Expression Profiles in the Brains of Mice Infected with Scrapie Agents 139A, ME7 and S15. Emerg. Microbes Infect. 2016, 5, e115. [CrossRef] [PubMed]

122. Saba, R.; Goodman, C.D.; Huzarewich, R.L.C.H.; Robertson, C.; Booth, S.A. A MiRNA Signature of Prion Induced Neurodegeneration. PLoS ONE 2008, 3, e3652. [CrossRef] [PubMed]

123. Majer, A.; Medina, S.J.; Niu, Y.; Abrenica, B.; Manguiat, K.J.; Frost, K.L.; Philipson, C.S.; Sorensen, D.L.; Booth, S.A. Early Mechanisms of Pathobiology Are Revealed by Transcriptional Temporal Dynamics in Hippocampal CA1 Neurons of Prion Infected Mice. PLoS Pathog. 2012, 8. [CrossRef] [PubMed]

124. Boese, A.S.; Saba, R.; Campbell, K.; Majer, A.; Medina, S.; Burton, L.; Booth, T.F.; Chong, P.; Westmacott, G.; Dutta, S.M.; et al. MicroRNA Abundance Is Altered in Synaptoneurosomes during Prion Disease. Mol. Cell. Neurosci. 2016, 71, 13-24. [CrossRef]

125. Saba, R.; Gushue, S.; Huzarewich, R.L.C.H.; Manguiat, K.; Medina, S.; Robertson, C.; Booth, S.A. MicroRNA 146a (MiR-146a) Is Over-Expressed during Prion Disease and Modulates the Innate Immune Response and the Microglial Activation State. PLoS ONE 2012, 7, e30832. [CrossRef]

126. Misra, U.K.; Kalita, J. Overview: Japanese Encephalitis. Prog. Neurobiol. 2010, 91, 108-120. [CrossRef] [PubMed]

127. Campbell, G.L.; Hills, S.L.; Fischer, M.; Jacobson, J.A.; Hoke, C.H.; Hombach, J.M.; Marfin, A.A.; Solomon, T.; Tsai, T.F.; Tsu, V.D.; et al. Estimated Global Incidence of Japanese Encephalitis: A Systematic Review. Bull. World Health Organ. 2011, 89, 766-774. [CrossRef] [PubMed] 
128. Lannes, N.; Summerfield, A.; Filgueira, L. Regulation of Inflammation in Japanese Encephalitis. J. Neuroinflamm. 2017, 14, 158. [CrossRef] [PubMed]

129. Unni, S.K.; Rํ̌ek, D.; Chhatbar, C.; Mishra, R.; Johri, M.K.; Singh, S.K. Japanese Encephalitis Virus: From Genome to Infectome. Microbes Infect. 2011, 13, 312-321. [CrossRef] [PubMed]

130. Thounaojam, M.C.; Kundu, K.; Kaushik, D.K.; Swaroop, S.; Mahadevan, A.; Shankar, S.K.; Basu, A. MicroRNA 155 Regulates Japanese Encephalitis Virus-Induced Inflammatory Response by Targeting Src Homology 2-Containing Inositol Phosphatase 1. J. Virol. 2014, 88, 4798-4810. [CrossRef] [PubMed]

131. Pareek, S.; Roy, S.; Kumari, B.; Jain, P.; Banerjee, A.; Vrati, S. MiR-155 Induction in Microglial Cells Suppresses Japanese Encephalitis Virus Replication and Negatively Modulates Innate Immune Responses. J. Neuroinflamm. 2014, 11, 97. [CrossRef] [PubMed]

132. Sharma, N.; Verma, R.; Kumawat, K.; Basu, A.; Singh, S.K. MiR-146a Suppresses Cellular Immune Response during Japanese Encephalitis Virus JaOArS982 Strain Infection in Human Microglial Cells. J. Neuroinflamm. 2015, 12, 30. [CrossRef] [PubMed]

133. Deng, M.; Du, G.; Zhao, J.; Du, X. MiR-146a Negatively Regulates the Induction of Proinflammatory Cytokines in Response to Japanese Encephalitis Virus Infection in Microglial Cells. Arch. Virol. 2017, 162, 1495-1505. [CrossRef]

134. Smith, J.L.; Jeng, S.; McWeeney, S.K.; Hirsch, A.J. A MicroRNA Screen Identifies the Wnt Signaling Pathway as a Regulator of the Interferon Response during Flavivirus Infection. J. Virol. 2017, 91. [CrossRef] [PubMed]

135. Sharma, N.; Kumawat, K.L.; Rastogi, M.; Basu, A.; Singh, S.K. Japanese Encephalitis Virus Exploits the MicroRNA-432 to Regulate the Expression of Suppressor of Cytokine Signaling (SOCS) 5. Sci. Rep. 2016, 6, 27685. [CrossRef] [PubMed]

136. Hazra, B.; Kumawat, K.L.; Basu, A. The Host MicroRNA MiR-301a Blocks the IRF1-Mediated Neuronal Innate Immune Response to Japanese Encephalitis Virus Infection. Sci. Signal. 2017, 10, eaaf5185. [CrossRef]

137. Thounaojam, M.C.; Kaushik, D.K.; Kundu, K.; Basu, A. MicroRNA-29b Modulates Japanese Encephalitis Virus-Induced Microglia Activation by Targeting Tumor Necrosis Factor Alpha-Induced Protein 3. J. Neurochem. 2014, 129, 143-154. [CrossRef] [PubMed]

138. Wan, S.; Ashraf, U.; Ye, J.; Duan, X.; Zohaib, A.; Wang, W.; Chen, Z.; Zhu, B.; Li, Y.; Chen, H.; et al. MicroRNA-22 Negatively Regulates Poly(I:C)-Triggered Type I Interferon and Inflammatory Cytokine Production via Targeting Mitochondrial Antiviral Signaling Protein (MAVS). Oncotarget 2016, 7, 76667-76683. [CrossRef] [PubMed]

139. Cui, W.; Li, W.; Cheng, P.; Nie, S. MiR-370 Mimic Inhibits Replication of Japanese Encephalitis Virus in Glioblastoma Cells. Neuropsychiatr. Dis. Treat. 2016, 12, 2411-2417. [CrossRef]

140. Ashraf, U.; Zhu, B.; Ye, J.; Wan, S.; Nie, Y.; Chen, Z.; Cui, M.; Wang, C.; Duan, X.; Zhang, H.; et al. MicroRNA-19b-3p Modulates Japanese Encephalitis Virus-Mediated Inflammation via Targeting RNF11. J. Virol. 2016, 90, 4780-4795. [CrossRef]

141. Zhu, B.; Ye, J.; Nie, Y.; Ashraf, U.; Zohaib, A.; Duan, X.; Fu, Z.F.; Song, Y.; Chen, H.; Cao, S. MicroRNA-15b Modulates Japanese Encephalitis Virus-Mediated Inflammation via Targeting RNF125. J. Immunol. 2015, 195, 2251-2262. [CrossRef] [PubMed]

142. Rechenchoski, D.Z.; Faccin-Galhardi, L.C.; Linhares, R.E.C.; Nozawa, C. Herpesvirus: An Underestimated Virus. Folia Microbiol. 2017, 62, 151-156. [CrossRef] [PubMed]

143. Cliffe, A.R.; Wilson, A.C. Restarting Lytic Gene Transcription at the Onset of Herpes Simplex Virus Reactivation. J. Virol. 2017, 91, 1-6. [CrossRef]

144. Bradshaw, M.J.; Venkatesan, A. Herpes Simplex Virus-1 Encephalitis in Adults: Pathophysiology, Diagnosis, and Management. Neurotherapeutics 2016, 13, 493-508. [CrossRef]

145. Rabinstein, A.A. Herpes Virus Encephalitis in Adults. Neurol. Clin. 2017, 35, 695-705. [CrossRef]

146. Mancini, M.; Vidal, S.M. Insights into the Pathogenesis of Herpes Simplex Encephalitis from Mouse Models. Mamm. Genome 2018, 29, 425-445. [CrossRef]

147. Sun, L.; Li, Q. The MiRNAs of Herpes Simplex Virus (HSV). Virol. Sin. 2012, 27, 332-337. [CrossRef] [PubMed]

148. Pan, D.; Flores, O.; Umbach, J.L.; Pesola, J.M.; Bentley, P.; Rosato, P.C.; Leib, D.A.; Cullen, B.R.; Coen, D.M. A Neuron-Specific Host MicroRNA Targets Herpes Simplex Virus-1 ICP0 Expression and Promotes Latency. Cell Host Microbe 2014, 15, 446-456. [CrossRef] [PubMed] 
149. Hill, J.M.; Zhao, Y.; Clement, C.; Neumann, D.M.; Lukiw, W.J. HSV-1 Infection of Human Brain Cells Induces MiRNA-146a and Alzheimer-Type Inflammatory Signaling. Neuroreport 2009, 20, 1500-1505. [CrossRef] [PubMed]

150. Bhela, S.; Mulik, S.; Gimenez, F.; Reddy, P.B.J.; Richardson, R.L.; Varanasi, S.K.; Jaggi, U.; Xu, J.; Lu, P.Y.; Rouse, B.T. Role of MiR-155 in the Pathogenesis of Herpetic Stromal Keratitis. Am. J. Pathol. 2015, 185, 1073-1084. [CrossRef]

151. Majer, A.; Caligiuri, K.A.; Gale, K.K.; Niu, Y.; Phillipson, C.S.; Booth, T.F.; Booth, S.A. Induction of Multiple MiR-200/182 Members in the Brains of Mice Are Associated with Acute Herpes Simplex Virus 1 Encephalitis. PLoS ONE 2017, 12, e0169081. [CrossRef]

152. Bhela, S.; Reddy, P.B.J.; Richardson, R.L.; Rajasagi, N.K.; Osmand, A.P.; Rouse, B.T.; Veiga-Parga, T.; Gimenez, F.; Mulik, S. Critical Role of MicroRNA-155 in Herpes Simplex Encephalitis. J. Immunol. 2014, 192, 2734-2743. [CrossRef] [PubMed]

153. Ru, J.; Sun, H.; Fan, H.; Wang, C.; Li, Y.; Liu, M.; Tang, H. MiR-23a Facilitates the Replication of HSV-1 through the Suppression of Interferon Regulatory Factor 1. PLoS ONE 2014, 9, e114021. [CrossRef]

154. Xie, Y.; He, S.; Wang, J. MicroRNA-373 Facilitates HSV-1 Replication through Suppression of Type I IFN Response by Targeting IRF1. Biomed. Pharmacother. 2018, 97, 1409-1416. [CrossRef]

155. Meschia, J.F.; Brott, T. Ischaemic Stroke. Eur. J. Neurol. 2018, 25, 35-40. [CrossRef]

156. Patel, R.A.G.; McMullen, P.W. Neuroprotection in the Treatment of Acute Ischemic Stroke. Prog. Cardiovasc. Dis. 2017, 59, 542-548. [CrossRef]

157. Puig, B.; Brenna, S.; Magnus, T. Molecular Communication of a Dying Neuron in Stroke. Int. J. Mol. Sci. 2018, 19, 2834. [CrossRef]

158. Jin, R.; Liu, L.; Zhang, S.; Nanda, A.; Li, G. Role of Inflammation and Its Mediators in Acute Ischemic Stroke. J. Cardiovasc. Transl. Res. 2013, 6, 834-851. [CrossRef]

159. Li, G.; Morris-Blanco, K.C.; Lopez, M.S.; Yang, T.; Zhao, H.; Vemuganti, R.; Luo, Y. Impact of MicroRNAs on Ischemic Stroke: From Pre- to Post-Disease. Prog. Neurobiol. 2018, 163-164, 59-78. [CrossRef]

160. Huang, L.; Ma, Q.; Li, Y.; Li, B.; Zhang, L. Inhibition of MicroRNA-210 Suppresses pro-Inflammatory Response and Reduces Acute Brain Injury of Ischemic Stroke in Mice. Exp. Neurol. 2018, 300, 41-50. [CrossRef]

161. Ouyang, Y.B.; Lu, Y.; Yue, S.; Xu, L.J.; Xiong, X.X.; White, R.E.; Sun, X.; Giffard, R.G. MiR-181 Regulates GRP78 and Influences Outcome from Cerebral Ischemia in Vitro and in Vivo. Neurobiol. Dis. 2012, 45, 555-563. [CrossRef]

162. Ma, Q.; Zhao, H.; Tao, Z.; Wang, R.; Liu, P.; Han, Z.; Ma, S.; Luo, Y.; Jia, J. MicroRNA-181c Exacerbates Brain Injury in Acute Ischemic Stroke. Aging Dis. 2016, 7, 705-714. [CrossRef]

163. Xu, L.-J.; Ouyang, Y.-B.; Xiong, X.; Stary, C.M.; Giffard, R.G. Post-Stroke Treatment with MiR-181 Antagomir Reduces Injury and Improves Long-Term Behavioral Recovery in Mice after Focal Cerebral Ischemia. Exp. Neurol. 2015, 264, 1-7. [CrossRef] [PubMed]

164. Liu, D.Z.; Tian, Y.; Ander, B.P.; Xu, H.; Stamova, B.S.; Zhan, X.; Turner, R.J.; Jickling, G.; Sharp, F.R. Brain and Blood MicroRNA Expression Profiling of Ischemic Stroke, Intracerebral Hemorrhage, and Kainate Seizures. J. Cereb. Blood Flow Metab. 2010, 30, 92-101. [CrossRef]

165. Caballero-Garrido, E.; Pena-Philippides, J.C.; Lordkipanidze, T.; Bragin, D.; Yang, Y.; Erhardt, E.B.; Roitbak, T. In Vivo Inhibition of Mir-155 Promotes Recovery after Experimental Mouse Stroke. J. Neurosci. 2015, 35, 12446-12464. [CrossRef] [PubMed]

166. Pena-Philippides, J.C.; Caballero-Garrido, E.; Lordkipanidze, T.; Roitbak, T. In Vivo Inhibition of MiR-155 Significantly Alters Post-Stroke Inflammatory Response. J. Neuroinflamm. 2016, 13, 287. [CrossRef]

167. Hamzei Taj, S.; Kho, W.; Aswendt, M.; Collmann, F.M.; Green, C.; Adamczak, J.; Tennstaedt, A.; Hoehn, M. Dynamic Modulation of Microglia/Macrophage Polarization by MiR-124 after Focal Cerebral Ischemia. J. Neuroimmune Pharmacol. 2016, 11, 733-748. [CrossRef] [PubMed]

168. Hamzei Taj, S.; Kho, W.; Riou, A.; Wiedermann, D.; Hoehn, M. MiRNA-124 Induces Neuroprotection and Functional Improvement after Focal Cerebral Ischemia. Biomaterials 2016, 91, 151-165. [CrossRef] [PubMed]

169. Zhao, H.; Wang, J.; Gao, L.; Wang, R.; Liu, X.; Gao, Z.; Tao, Z.; Xu, C.; Song, J.; Ji, X.; et al. MiRNA-424 Protects against Permanent Focal Cerebral Ischemia Injury in Mice Involving Suppressing Microglia Activation. Stroke 2013, 44, 1706-1713. [CrossRef] 
170. Liu, P.; Zhao, H.; Wang, R.; Wang, P.; Tao, Z.; Gao, L.; Yan, F.; Liu, X.; Yu, S.; Ji, X.; et al. MicroRNA-424 Protects against Focal Cerebral Ischemia and Reperfusion Injury in Mice by Suppressing Oxidative Stress. Stroke 2015, 46, 513-519. [CrossRef]

171. Yu, H.; Wu, M.; Zhao, P.; Huang, Y.; Wang, W.; Yin, W. Neuroprotective Effects of Viral Overexpression of MicroRNA-22 in Rat and Cell Models of Cerebral Ischemia-Reperfusion Injury. J. Cell. Biochem. 2015, 116, 233-241. [CrossRef]

172. Corrigan, J.D.; Hammond, F.M. Traumatic Brain Injury as a Chronic Health Condition. Arch. Phys. Med. Rehabil. 2013, 94, 1199-1201. [CrossRef]

173. Maas, A.I.; Stocchetti, N.; Bullock, R. Moderate and Severe Traumatic Brain Injury in Adults. Lancet Neurol. 2008, 7, 728-741. [CrossRef]

174. Bramlett, H.M.; Dietrich, W.D. Long-Term Consequences of Traumatic Brain Injury: Current Status of Potential Mechanisms of Injury and Neurological Outcomes. J. Neurotrauma 2014, 32, 1834-1848. [CrossRef] [PubMed]

175. Jassam, Y.N.; Izzy, S.; Whalen, M.; McGavern, D.B.; El Khoury, J. Neuroimmunology of Traumatic Brain Injury: Time for a Paradigm Shift. Neuron 2017, 95, 1246-1265. [CrossRef]

176. Ge, X.; Han, Z.; Chen, F.; Wang, H.; Zhang, B.; Jiang, R.; Lei, P.; Zhang, J. MiR-21 Alleviates Secondary Blood-Brain Barrier Damage after Traumatic Brain Injury in Rats. Brain Res. 2015, 1603, 150-157. [CrossRef]

177. Harrison, E.B.; Hochfelder, C.G.; Lamberty, B.G.; Meays, B.M.; Morsey, B.M.; Kelso, M.L.; Fox, H.S.; Yelamanchili, S.V. Traumatic Brain Injury Increases Levels of MiR-21 in Extracellular Vesicles: Implications for Neuroinflammation. FEBS Open Bio. 2016, 6, 835-846. [CrossRef] [PubMed]

178. Ge, X.-T.; Lei, P.; Wang, H.-C.; Zhang, A.-L.; Han, Z.-L.; Chen, X.; Li, S.-H.; Jiang, R.-C.; Kang, C.-S.; Zhang, J.-N. MiR-21 Improves the Neurological Outcome after Traumatic Brain Injury in Rats. Sci. Rep. 2015, 4, 6718. [CrossRef] [PubMed]

179. Redell, J.B.; Liu, Y.; Dash, P.K. Traumatic Brain Injury Alters Expression of Hippocampal MicroRNAs: Potential Regulators of Multiple Pathophysiological Processes. J. Neurosci. Res. 2009, 87, 1435-1448. [CrossRef]

180. Wang, W.X.; Huang, Q.; Hu, Y.; Stromberg, A.J.; Nelson, P.T. Patterns of MicroRNA Expression in Normal and Early Alzheimer's Disease Human Temporal Cortex: White Matter versus Gray Matter. Acta Neuropathol. 2011, 121, 193-205. [CrossRef] [PubMed]

181. Wang, W.X.; Wilfred, B.R.; Madathil, S.K.; Tang, G.; Hu, Y.; Dimayuga, J.; Stromberg, A.J.; Huang, Q.; Saatman, K.E.; Nelson, P.T. MiR-107 Regulates Granulin/Progranulin with Implications for Traumatic Brain Injury and Neurodegenerative Disease. Am. J. Pathol. 2010, 177, 334-345. [CrossRef]

182. Cenik, B.; Sephton, C.F.; Cenik, B.K.; Herz, J.; Yu, G. Progranulin: A Proteolytically Processed Protein at the Crossroads of Inflammation and Neurodegeneration. J. Biol. Chem. 2012, 287, 32298-32306. [CrossRef] [PubMed]

183. Wang, Y.; Guo, F.; Pan, C.; Lou, Y.; Zhang, P.; Guo, S.; Yin, J.; Deng, Z. Effects of Low Temperatures on Proliferation-Related Signaling Pathways in the Hippocampus after Traumatic Brain Injury. Exp. Biol. Med. 2012, 237, 1424-1432. [CrossRef]

184. Truettner, J.S.; Alonso, O.F.; Bramlett, H.M.; Dietrich, W.D. Therapeutic Hypothermia Alters MicroRNA Responses to Traumatic Brain Injury in Rats. J. Cereb. Blood Flow Metab. 2011, 31, 1897-1907. [CrossRef]

185. Truettner, J.S.; Motti, D.; Dietrich, W.D. MicroRNA Overexpression Increases Cortical Neuronal Vulnerability to Injury. Brain Res. 2013, 1533, 122-130. [CrossRef] [PubMed]

186. Wang, W.-X.; Visavadiya, N.P.; Pandya, J.D.; Nelson, P.T.; Sullivan, P.G.; Springer, J.E. Mitochondria-Associated MicroRNAs in Rat Hippocampus Following Traumatic Brain Injury. Exp. Neurol. 2015, 265, 84-93. [CrossRef] [PubMed]

187. Henry, R.J.; Doran, S.J.; Barrett, J.P.; Meadows, V.E.; Sabirzhanov, B.; Stoica, B.A.; Loane, D.J.; Faden, A.I. Inhibition of MiR-155 Limits Neuroinflammation and Improves Functional Recovery After Experimental Traumatic Brain Injury in Mice. Neurotherapeutics 2019, 16, 216-230. [CrossRef]

188. Zhang, Z.-J.; Guo, J.-S.; Li, S.-S.; Wu, X.-B.; Cao, D.-L.; Jiang, B.-C.; Jing, P.-B.; Bai, X.-Q.; Li, C.-H.; Wu, Z.-H.; et al. TLR8 and Its Endogenous Ligand MiR-21 Contribute to Neuropathic Pain in Murine DRG. J. Exp. Med. 2018, 215, 3019-3037. [CrossRef] [PubMed] 
189. Abreu, C.M.; Soares-dos-Reis, R.; Melo, P.N.; Relvas, J.B.; Guimarães, J.; Sá, M.J.; Cruz, A.P.; Mendes Pinto, I. Emerging Biosensing Technologies for Neuroinflammatory and Neurodegenerative Disease Diagnostics. Front. Mol. Neurosci. 2018, 11, 164. [CrossRef]

190. Morand, P.; Lecuit, M.; Piroth, L.; Crabol, Y.; Honnorat, J.; Stahl, J.P.; Fillatre, P. Infectious Encephalitis: Management without Etiological Diagnosis 48 Hours after Onset. Méd. Mal. Infect. 2017, 47, $236-251$. [CrossRef]

191. Cook, G.A.; Hawley, J.S. A Review of Mild Traumatic Brain Injury Diagnostics: Current Perspectives, Limitations, and Emerging Technology. Mil. Med. 2014, 179, 1083-1089. [CrossRef]

192. Backes, C.; Meese, E.; Keller, A. Specific MiRNA Disease Biomarkers in Blood, Serum and Plasma: Challenges and Prospects. Mol. Diagn. Ther. 2016, 20, 509-518. [CrossRef]

193. Gandhi, R. MiRNA in Multiple Sclerosis: Search for Novel Biomarkers. Mult. Scler. J. 2015, 21, $1095-1103$. [CrossRef]

194. Mushtaq, G.; Greig, N.H.; Shaik, M.M.; Tamargo, I.A.; Kamal, M.A. MiRNAs as Circulating Biomarkers for Alzheimer's Disease and Parkinson's Disease. Med. Chem. 2016, 12, 217-225. [CrossRef]

195. Kanata, E.; Thüne, K.; Xanthopoulos, K.; Ferrer, I.; Dafou, D.; Zerr, I.; Sklaviadis, T.; Llorens, F. MicroRNA Alterations in the Brain and Body Fluids of Humans and Animal Prion Disease Models: Current Status and Perspectives. Front. Aging Neurosci. 2018. [CrossRef] [PubMed]

196. Goswami, S.; Banerjee, A.; Kumari, B.; Bandopadhyay, B.; Bhattacharya, N.; Basu, N.; Vrati, S.; Banerjee, A. Differential Expression and Significance of Circulating MicroRNAs in Cerebrospinal Fluid of Acute Encephalitis Patients Infected with Japanese Encephalitis Virus. Mol. Neurobiol. 2017. [CrossRef] [PubMed]

197. Dewdney, B.; Trollope, A.; Moxon, J.; Thomas Manapurathe, D.; Biros, E.; Golledge, J. Circulating MicroRNAs as Biomarkers for Acute Ischemic Stroke: A Systematic Review. J. Stroke Cerebrovasc. Dis. 2018. [CrossRef] [PubMed]

198. Martinez, B.; Peplow, P. MicroRNAs as Diagnostic Markers and Therapeutic Targets for Traumatic Brain Injury. Neural Regen. Res. 2017, 12, 1749. [CrossRef]

199. Wang, J.; Chen, J.; Sen, S. MicroRNA as Biomarkers and Diagnostics. J. Cell. Physiol. 2016, 231, 25-30. [CrossRef]

200. Burgos, K.; Malenica, I.; Metpally, R.; Courtright, A.; Rakela, B.; Beach, T.; Shill, H.; Adler, C.; Sabbagh, M.; Villa, S.; et al. Profiles of Extracellular MiRNA in Cerebrospinal Fluid and Serum from Patients with Alzheimer's and Parkinson's Diseases Correlate with Disease Status and Features of Pathology. PLoS ONE 2014, 9, e94839. [CrossRef]

201. Pereira, P.; Queiroz, J.A.; Figueiras, A.; Sousa, F. Current Progress on MicroRNAs-Based Therapeutics in Neurodegenerative Diseases. Wiley Interdiscip. Rev. RNA 2017, 8, e1409. [CrossRef]

202. Rupaimoole, R.; Slack, F.J. MicroRNA Therapeutics: Towards a New Era for the Management of Cancer and Other Diseases. Nat. Rev. Drug Discov. 2017, 16, 203-222. [CrossRef]

203. Van Rooij, E.; Kauppinen, S. Development of MicroRNA Therapeutics Is Coming of Age. EMBO Mol. Med. 2014, 6, 851-864. [CrossRef]

204. Li, Z.; Rana, T.M. Therapeutic Targeting of MicroRNAs: Current Status and Future Challenges. Nat. Rev. Drug Discov. 2014, 13, 622-638. [CrossRef] [PubMed]

205. Chen, J.; Xie, J. Progress on RNAi-Based Molecular Medicines. Int. J. Nanomed. 2012, 7, 3971. [CrossRef]

206. Yin, H.; Kanasty, R.L.; Eltoukhy, A.A.; Vegas, A.J.; Dorkin, J.R.; Anderson, D.G. Non-Viral Vectors for Gene-Based Therapy. Nat. Rev. Genet. 2014, 15, 541-555. [CrossRef] [PubMed]

207. Aryal, M.; Arvanitis, C.D.; Alexander, P.M.; McDannold, N. Ultrasound-Mediated Blood-Brain Barrier Disruption for Targeted Drug Delivery in the Central Nervous System. Adv. Drug Deliv. Rev. 2014, 72, 94-109. [CrossRef]

208. Choudhury, S.R.; Hudry, E.; Maguire, C.A.; Sena-Esteves, M.; Breakefield, X.O.; Grandi, P. Viral Vectors for Therapy of Neurologic Diseases. Neuropharmacology 2017, 120, 63-80. [CrossRef] [PubMed]

(C) 2019 by the authors. Licensee MDPI, Basel, Switzerland. This article is an open access article distributed under the terms and conditions of the Creative Commons Attribution (CC BY) license (http://creativecommons.org/licenses/by/4.0/). 